Prepared in cooperation with the New Hampshire Department of Environmental Services and the New Hampshire Geological Survey

\title{
Preliminary Assessment of Trends in Static Water Levels in Bedrock Wells in New Hampshire, 1984 to 2007
}

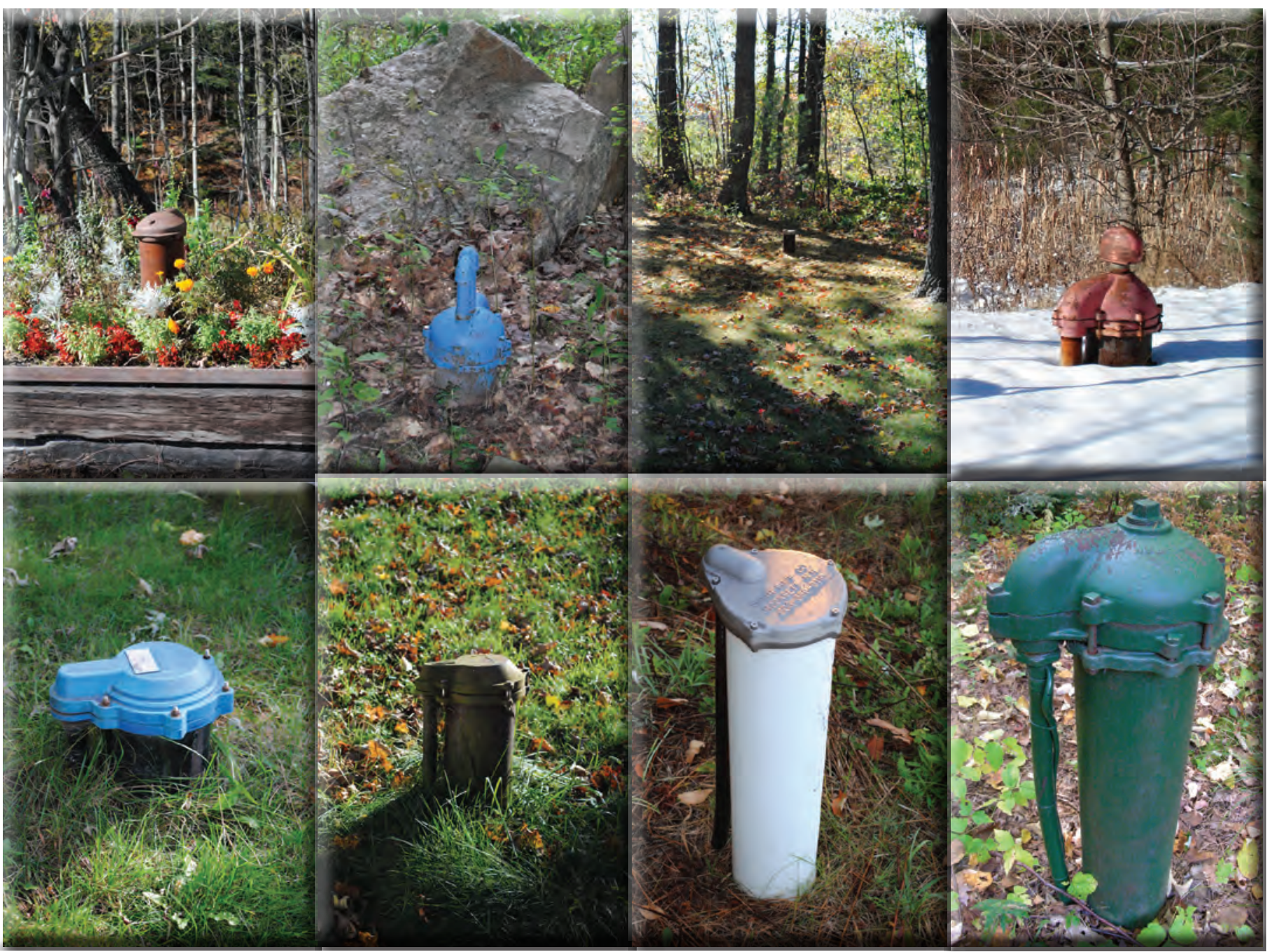

Open-File Report 2010-1189 
Cover. Mosaic of well heads from bedrock wells from across New Hampshire (photographs courtesy of Marcel Belaval, U.S. Environmental Protection Agency; and James Degnan and Sarah Flanagan, U.S. Geological Survey). 


\section{Preliminary Assessment of Trends in Static Water Levels in Bedrock Wells in New Hampshire, 1984 to 2007}

By Joseph D. Ayotte, Brandon M. Kernen, David R. Wunsch, Denise M. Argue, Derek S. Bennett, Thomas J. Mack

Prepared in cooperation with the New Hampshire Department of Environmental Services and the New Hampshire Geological Survey

Open-File Report 2010-1189 


\title{
U.S. Department of the Interior \\ KEN SALAZAR, Secretary \\ U.S. Geological Survey \\ Marcia K. McNutt, Director
}

\section{U.S. Geological Survey, Reston, Virginia: 2010}

\author{
For more information on the USGS — the Federal source for science about the Earth, its natural and living resources, \\ natural hazards, and the environment, visit http://www.usgs.gov or call 1-888-ASK-USGS \\ For an overview of USGS information products, including maps, imagery, and publications, \\ visit http://www.usgs.gov/pubprod \\ To order this and other USGS information products, visit http://store.usgs.gov
}

Any use of trade, product, or firm names is for descriptive purposes only and does not imply endorsement by the U.S. Government.

Although this report is in the public domain, permission must be secured from the individual copyright owners to reproduce any copyrighted materials contained within this report.

Suggested citation:

Ayotte, Joseph D., Kernen, Brandon, M., Wunsch, David R., Argue, Denise M., Bennett, Derek S., Mack, Thomas J., 2010, Preliminary assessment of water levels in bedrock wells in New Hampshire, 1984 to 2007: U.S. Geological Survey Open-File Report 2010-1189, 30 p., at http://pubs.usgs.gov/of/2010/1189. 


\section{Acknowledgments}

The authors acknowledge the support and input of the drilling and environmental-science communities in the development of this report. Special thanks are extended to the drilling industry for their effort in providing well-completion reports and to the NHDES staff, particularly Richard Schofield and Frederick Chormann, who have over the years carefully managed these data. Thanks also to Allen Shapiro, Rodney Sheets, Leslie DeSimone, and Dennis Risser of the USGS for discussion of data and analyses. Mary Ashman edited the report, M. Patricia Lee and Mark Bonito provided layout and graphic assistance. 
This page has been left blank intentionally. 


\section{Contents}

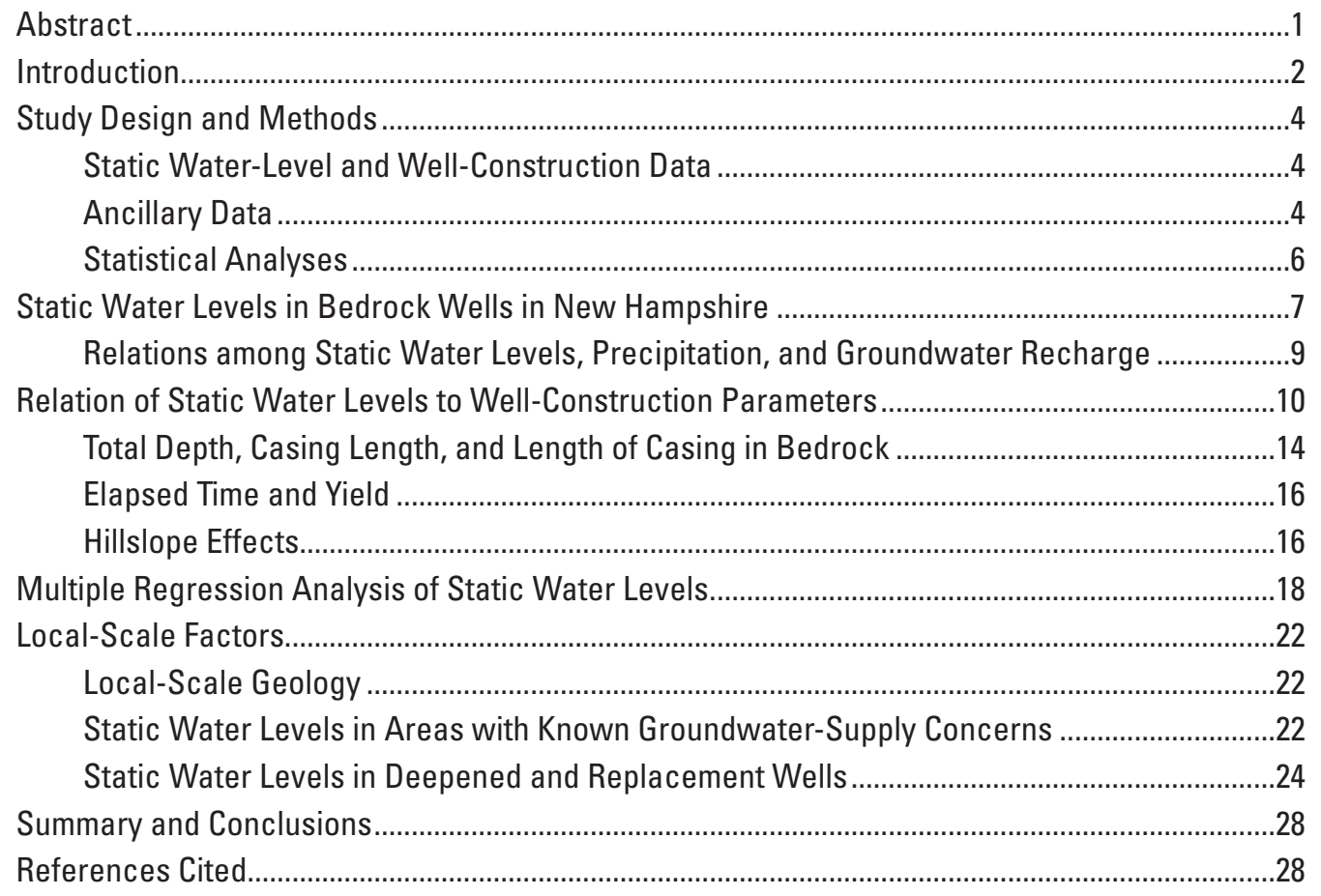

\section{Figures}

1. Map showing locations of 29,408 geolocated wells with static water level data in New Hampshire

2. Graph showing A) mean static water level in bedrock wells in New Hampshire, 1984 through 2007, B) population in New Hampshire, 1984 through 2007; and C) mean static water level as a function of population

3. Graph showing mean quarterly static water levels in bedrock wells in New Hampshire, 1984 through 2007.

4. Graphs showing A) Mean annual precipitation at Portsmouth, Durham, and Concord, New Hampshire, 1984-2005; B) third-quarter base flow at Beaver Brook, Oyster River, and Soucook River; and C) mean quarterly static water levels, 1984-2007...

5. Boxplots summarizing A) quarterly precipitation at Concord Municipal Airport; B) quarterly base flow at Oyster River, near Durham, NH (01073000); and C) mean quarterly static water level statewide by quarter, 1984- 2007.

6. Graphs showing A) mean total well depth by year and quarter; B) mean casing length, mean length of casing in bedrock, and mean bedrock depth by year and quarter; $\mathrm{C}$ ) mean total well depth and mean length of casing in bedrock as a function of mean static water level; and D) mean length of casing in bedrock as a function of mean total well depth

7. Graphs showing mean length of water column in bedrock wells in New Hampshire, 1984 through 2007

8. Boxplots summarizing A) mean static water level, B) mean total well depth, C) 
mean casing length, D) mean length of casing in bedrock, E) mean bedrock depth, and F) mean reported yield, for categories of elapsed time between well construction and static water-level measurement.

9. Boxplots summarizing A) mean static water level, B) mean total well depth, C) mean casing length, D) mean length of casing in bedrock, E) mean bedrock depth, and F) mean reported yield, for categories of height above the minimum elevation within a 1,640 -foot (500-meter) radius

10. Graphs showing mean elevation of well, mean slope at the well, and mean height above minimum elevation within 1,640-foot (500-meter) radius by year and quarter, 1984-2007.

11. Boxplots summarizing A) mean quarterly static water level, B) mean total well depth, and C) mean length of casing in bedrock for major lithologic groups in New Hampshire (groups from Robinson and Kapo, 2003)

12. Bar graphs showing relation of mean static water level to binary categories of height of well above minimum elevation within a 1,640-foot (500-meter) radius of well ( $<100$ feet ( 30 meters) and $\geq 100$ feet ( 30 meters)) and aspect ( $N$ refers to $\geq 300$ degrees and $\leq 60$ degrees; $S$ refers to $>60$ degrees and $<300$ degrees), by town

13. Map showing locations of wells reported as replacement wells (black circles) or deepened wells (green triangles) in New Hampshire, 1984-2007.

14. Graphs showing A) mean static water level, B) mean total well depth, C) mean elevation, and D) mean height above minimum elevation within a 1,640-foot (500-meter) radius, by categories of reported reason for well installation, New Hampshire, 1984-2007.

\section{Tables}

1. Names and descriptions of fields in New Hampshire Department of Environmental Services database of wells.

2. Types and sources of ancillary data tested in this study

3. Ten most frequently reported static-water levels, well depths, bedrock depths, casing lengths, lengths of casing in bedrock, and yields for 56,437 wells in the New Hampshire Department of Environmental Services database between 1984 and 2007 ...7

4. Summary of trend-test statistics for mean static water level and related well parameters aggregated by year and quarter from 1984-2007

5. Spearman rank correlation coefficients for mean static water level and means of selected physical and hydraulic parameters by year and quarter, 1984-2007 ( $\mathrm{n}=96) . .14$

6. Correlation of mean static water level with year measured, mean total depth, casing length, length of casing in bedrock, elapsed time, and yield, for grouted and nongrouted wells by year and quarter, 1999-2007 $(n=36)$

7. Correlation of mean static water level with year measured, mean total depth, casing length, length of casing in bedrock, elapsed time, and yield for categories of elapsed time between construction and measurement of static water level; aggregated by year and quarter, 1984-2007 $(n=96)$

8. Comparison of mean quarterly values of selected variables for wells in igneous and metamorphic rocks

9. Multiple regression models on the means of logarithms of static water levels by major rock type in New Hampshire 


\section{Conversion Factors}

\begin{tabular}{lll}
\hline Multiply & By & To obtain \\
\hline inch (in.) & Length & \\
inch (in.) & 2.54 & centimeter $(\mathrm{cm})$ \\
foot (ft) & 25.4 & millimeter $(\mathrm{mm})$ \\
mile (mi) & 0.3048 & meter $(\mathrm{m})$ \\
\hline & 1.609 & kilometer $(\mathrm{km})$ \\
\hline acre & Area & \\
square foot $\left(\mathrm{ft}^{2}\right)$ & 0.004047 & square kilometer $\left(\mathrm{km}^{2}\right)$ \\
square mile $\left(\mathrm{mi}^{2}\right)$ & 0.09290 & square meter $\left(\mathrm{m}^{2}\right)$ \\
\hline & 2.590 & square kilometer $\left(\mathrm{km}^{2}\right)$ \\
\hline gallon (gal) & Volume & \\
gallon (gal) & 3.785 & liter $(\mathrm{L})$ \\
\hline & 0.003785 & cubic meter $\left(\mathrm{m}^{3}\right)$ \\
\hline gallon per minute $(\mathrm{gal} / \mathrm{min})$ & Flow rate & liter per second $(\mathrm{L} / \mathrm{s})$ \\
\hline
\end{tabular}

Temperature in degrees Celsius $\left({ }^{\circ} \mathrm{C}\right)$ may be converted to degrees Fahrenheit $\left({ }^{\circ} \mathrm{F}\right)$ as follows:

$$
{ }^{\circ} \mathrm{F}=\left(1.8 \times^{\circ} \mathrm{C}\right)+32
$$

Vertical coordinate information is referenced to the North American Vertical Datum of 1988 (NAVD 88).

Horizontal coordinate information is referenced to the North American Datum of 1983 (NAD 83).

List of Acronyms

GPS Global positioning system

HAVB Height above minimum elevation (within a 1,640-ft (500-m) radius of a well)

NHDES New Hampshire Department of Environmental Services

NHGS New Hampshire Geological Survey

PART Streamflow partitioning program to estimate a daily record of base flow (groundwater discharge) from streamflow

SWL Static water level

WWB Water Well Board

WWI Water Well Inventory 
This page has been left blank intentionally. 


\title{
Preliminary Assessment of Trends in Static Water Levels in Bedrock Wells in New Hampshire, 1984 to 2007
}

\author{
By Joseph D. Ayotte, Brandon M. Kernen, ${ }^{1}$ David R. Wunsch, ${ }^{2}$ Denise M. Argue, Derek S. Bennett, ${ }^{1}$ and \\ Thomas J. Mack
}

\section{Abstract}

Analysis of nearly 60,000 reported values of static water level (SWL, as depth below land surface) in bedrock wells in New Hampshire, aggregated on a yearly basis, showed an apparent deepening of SWL of about $13 \mathrm{ft}(4 \mathrm{~m})$ over the period 1984-2007. Water-level data were one-time measurements at each well and were analyzed, in part, to determine if they were suitable for analysis of trends in groundwater levels across the state. Other well characteristics, however, also have been changing over time, such as total well depth, casing length, the length of casing in bedrock, and to some extent, well yield. Analyses indicated that many of the well construction variables are significantly correlated; the apparent declines in water levels may have been caused by some of these factors. Information on changes in water use for the period was not available, although water use may be an important factor affecting water levels.

Multiple regression models were used to determine the simultaneous effects of important variables on SWLs statewide. Models also were generated for each county, and the model-calculated results for counties were generally similar to the results for the state wide models.

The most significant predictors of mean SWL (aggregated by year and quarter) were total depth, the third quarter of the year (July-September), elevation, and height of well above minimum elevation within a 1,640-foot (500-meter) radius (hillslope factor). Casing length was a significant predictor of SWL for igneous-rock models and curvature of the land surface for metamorphic-rock models. Local geologic as well as landscape features appear to provide further explanation of SWL variation. For example, SWLs in wells completed in specific granites appear to be deeper than in other granites; this relation was also observed for different groups of metamorphic rocks.

A more detailed examination of data from six towns that report frequent complaints about low water supply from bedrock aquifer wells showed that hillslope position may play a role in the availability of water in wells. SWLs were commonly deeper (greater depth to water) for wells with more than $100 \mathrm{ft}(30 \mathrm{~m})$ of relief between the well and the lowest land-surface elevation within 1,640 $\mathrm{ft}(500 \mathrm{~m})$ of the well. For these high-relief wells, the depth to SWL was commonly greater for those that were on generally south-facing slopes, compared to wells on north-facing slopes.

Concerns about wells with very little water-producing capacity in localized areas of some towns may be better understood by considering some of the relations identified in this study. For example, the data show that the position of a well on a hillslope affects the SWL depth in that well; however, the data also indicate that the average yield of the well is lower for hillslope wells than for wells in lower relief areas. This relation indicates that as the hillslope factor increases (and SWLs become deeper), the amount of available water in the wells decreases. Knowledge of this relation indicates that deeper wells may be needed in areas of higher relief.

In areas with less extreme relief, the overall depths of wells have increased substantially more than the depths to the SWL. This indicates that the amount of water stored in wells (wellbore storage) has increased, and thus more water is available for use in the average well. As a result, more water may be used because it is available, possibly adding to the problem of local well interference or exacerbating drought-related well problems.

These data provided an opportunity to examine groundwater-level conditions across the state; however, the bedrock wells used in this study would not be suitable for rigorous evaluation of trends in SWL across the state because the locations and characteristics of the wells vary with time. Further, these wells cannot substitute for a carefully designed network of wells selected for the sole purpose of monitoring trends in water levels over time. The SWL data may be useful in the design of a monitoring network, and continued collection of water-level data from the bedrock wells could be used to augment data from monitoring wells.

\footnotetext{
${ }^{1}$ New Hampshire Department of Environmental Services.

${ }^{2}$ New Hampshire Geological Survey.
} 
Preliminary Assessment of Trends in Static Water Levels in Bedrock Wells in New Hampshire, 1984 to 2007

\section{Introduction}

The New Hampshire Water Well Board (WWB) is responsible for the inventory of all water wells completed in New Hampshire (Wunsch and Bennett, 2004). Well-completion reports have been required for all new water wells installed in New Hampshire since 1984, and reports must be submitted by drillers within 90 days of completing an installation. The data are included in the New Hampshire Water Well Inventory (WWI) database, which is currently (2010) administered by the New Hampshire Geological Survey of the New Hampshire Department of Environmental Services. Data on well construction, well performance, and location were collected as part of this program. Nearly 60,000 New Hampshire well-completion reports, of which about 29,000 include geographic information (fig. 1), contain static water-level (SWL) and other well-construction measurements for the period 1984-2007. SWL is defined in this study as the depth, measured from land surface, in feet, to water in a well. All SWL data used in this report represent one-time measurements that were generally made on the day drilling was completed.

New Hampshire encompasses an area of approximately $9,000 \mathrm{mi}^{2}\left(23,310 \mathrm{~km}^{2}\right)$ and had a population of 1.3 million people in 2008 (U.S. Census Bureau, 2009). Between 1980 and 2000, the population in the Seacoast region of southeastern New Hampshire increased 37 percent and is expected to increase another 25 percent by 2025 (Horn and others, 2007). The majority of New Hampshire's population obtains drinking water from groundwater withdrawn from private- and public-supply wells (Ayotte and others, 2008). In densely populated areas of the state, such as the Seacoast region and southern towns, supply wells may be placed in close proximity to each other. As population density increases, each additional well may be competing with existing wells for a finite amount of water. Such competition could potentially lead to systematic declines in groundwater levels.

Population growth in New Hampshire is expected to continue and with it the demand for water from the bedrock aquifer (Mack, 2009). The growth also could bring an increase in impervious-surface area through the building of new roads, parking lots, and homes, and increased use of sewering, which may further reduce recharge to the bedrock aquifer. The potential for widespread decline of bedrock groundwater levels has important implications for groundwater availability and the sustainability of water resources in New Hampshire. Modeling studies can be useful in determining the effects of changes in environmental factors on groundwater levels. A recent groundwater investigation in the Seacoast region of New Hampshire found that population growth, increased water demand, sewering, and climate change may all potentially lead to declining groundwater levels and base flows (Mack, 2009).

The potential effects of a changing climate on the groundwater resources of New Hampshire are also a concern. Recent research indicates that climate change has affected the hydrology of the northeastern U.S. (Hayhoe and others, 2007), and earlier spring runoffs have been correlated with rising air temperatures (Hodgkins and Dudley, 2006). Studies indicate that, in New England, base-flow discharge (groundwater discharge from aquifers) possibly has been declining, but none of the declines have been statistically significant (Hodgkins and others, 2005; Brutsaert, 2010). In one investigation, base flows correlated somewhat with precipitation (rather than temperature), but no consistent pattern was clear (Hodgkins and others, 2005). Actual water-level declines have been reported in other parts of the United States, for which the roles of global climate change or long-term cyclical climate patterns also are unclear (Skinner and others, 2007).

Understanding long-term trends in groundwater levels in New England's bedrock aquifers is problematic because of the small number of long-term monitoring wells in these aquifers. A network of monitoring wells that was designed to assess climatic factors in New Hampshire is primarily monitoring unconsolidated aquifers. Examples from a recent groundwater study illustrate the need for long-term data to accurately assess trends in areas where small changes are expected, and suggest that it is premature to draw conclusions about drought or declines caused by increased water use or climate change on the basis of only a few decades of data (Brutsaert, 2010).

Identification of declining groundwater levels and the factors associated with those apparent declines is vital to understanding the limitations of groundwater resources in bedrock aquifers. As an initial response to these concerns, a cooperative investigation involving the New Hampshire Department of Environmental Services (NHDES), New Hampshire Geological Survey (NHGS), and the U.S. Geological Survey (USGS) was initiated in 2008 to explore potential trends in SWL and possible factors related to SWLs statewide, regionally, and locally. In this investigation statistical analyses were used to assess water-level, geohydrologic, climatic, and demographic data to provide a preliminary understanding of groundwater levels in New Hampshire's bedrock aquifer. Multiple lines of evidence were used to develop hypotheses that might explain apparently deeper SWLs over time in wells used in the analysis.

This report describes increases in depth to SWLs in bedrock aquifer wells in New Hampshire from 1984 to 2007. Data from the State of New Hampshire water-well inventory were analyzed to relate SWL data to time and well-construction data. This investigation was statewide to regional in scope and focused on SWLs in the bedrock aquifer. The analyses presented do not address site-specific hydrologic issues. Further investigation of these data may provide additional understanding of the nature of and factors related to SWL measurements in wells drilled in bedrock aquifers. 

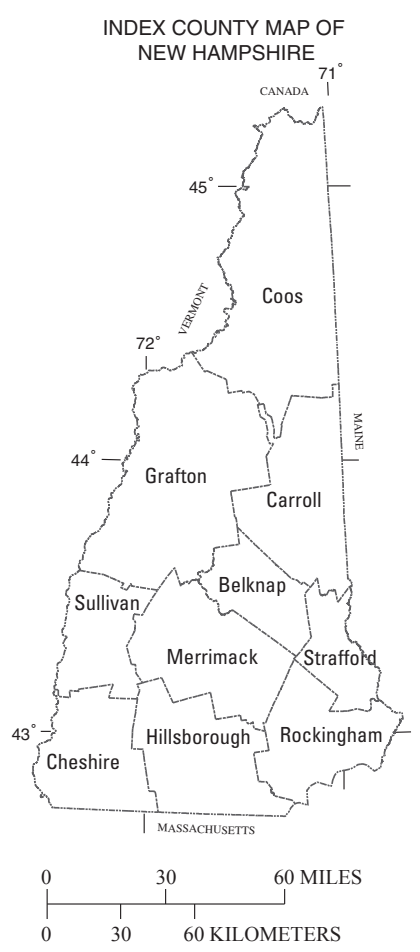

Base maps from USGS and NH GRANIT GIS digital data sources.

\section{EXPLANATION}

Town boundaries

\section{- Well locations}

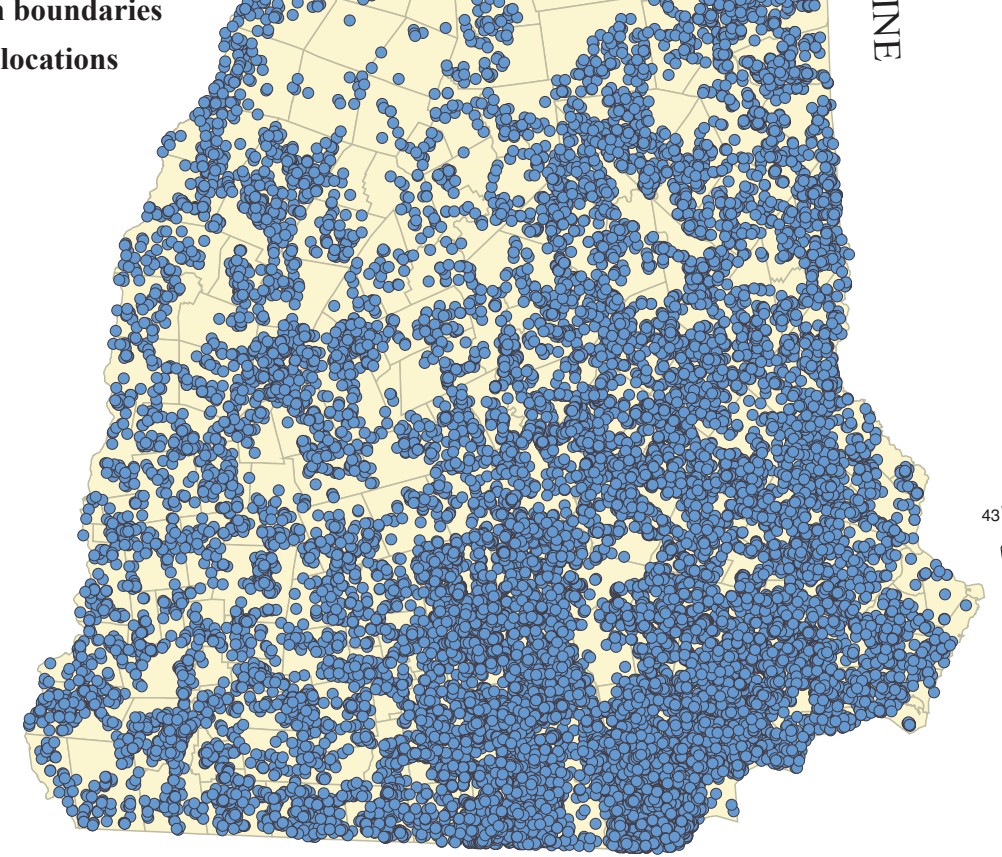

MASSACHUSETTS

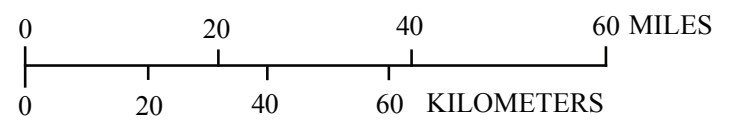

Figure 1. Map showing locations of 29,408 geolocated wells with static water level data in New Hampshire. 


\section{Study Design and Methods}

For this study, relations between information in well-completion reports and trends in the data over the period 1984-2007 were examined. Because the data were collected for tracking well installation and associated information and not for SWL-trend analysis, they do not include multiple measurements of SWL at individual wells over time; however, because of the large number of measurements, they could be used to determine general information about SWLs over time. Because the data also include information about well construction, they allow the relations between SWLs and factors such as well depth, casing, yield, as well as trends in such construction factors, to be determined.

\section{Static Water-Level and Well-Construction Data}

The WWI database contained 111,745 well-completion reports, of which 56,437 included SWL data, as of 2007. Because latitude and longitude information for about 29,000 of these wells was available, it could be used to obtain additional ancillary data from geographic-information system (GIS) databases. When the well-completion reporting system was initiated, the WWB located wells to the nearest second (within an error range of approximately $100 \mathrm{ft}(30 \mathrm{~m})$ in New Hampshire) on topographic maps and manually transcribed coordinates for entry into the database. Currently, most well locations are determined either by the driller using global positioning system (GPS) devices or by the NHGS using desktop analysis of aerial photography. As a result, the number of wells with positions determined accurately each year has increased substantially.

Well-completion reports include such information as: owner and address, driller, purpose (use) of well, well-completion date, depth to bedrock, depth drilled, type (setting) of well, length of casing, method of seal, yield, and SWL and date measured (table 1). Additional variables, such as the time elapsed between well completion and measurement of water level, are calculated from the original data. Similarly, the length of casing in bedrock was calculated as equal to the length of casing installed minus the reported depth to bedrock.

The SWL and other data were self-reported by the professionals who construct water wells and install pumps. Whereas these data are sufficiently accurate for the purposes for which they were collected, the nature of the data may affect the assessment of trends in water levels in bedrock wells in New Hampshire; however, no direct information is available to evaluate the accuracy of these values.

\section{Ancillary Data}

The New Hampshire SWL data were assessed with respect to ancillary data including demographic information, precipitation, streamflow, and geology (U.S. Geological Survey, 1993; U.S. Census Bureau, 2001; Robinson and Kapo, 2003; U.S. Geological Survey, 2004; U.S. Census Bureau, 2006; U.S. Geological Survey, 2008; National Climatic Data Center, 2009) (table 2). Annual total precipitation values for Concord, Manchester, and Portsmouth were obtained from National National Atmospheric and Oceanic Administration for the study period (National Climatic Data Center, 2009).

Changes in quarterly and annual estimated base flows for Beaver Brook (USGS streamgage 010965852) and the Oyster (01073000), Soucook (1089000), Smith (1078000), and Pemigewasset River (1076500) drainage basins were used for comparisons with water levels over the study period to provide an indication of groundwater recharge trends. These drainage basins were selected because they were gaged during the entire study period (U.S. Geological Survey, 2008), were relatively free from the effects of regulation, and represented the three physiographic provinces (Seaboard Lowland, New England Upland, and White Mountain) of New Hampshire (Flynn and Tasker, 2004). Base flows were calculated with hydrograph separation techniques from daily mean streamflow by the program PART (Rutledge, 1993, 1998). 
Table 1. Names and descriptions of fields in New Hampshire Department of Environmental Services database of wells.

\begin{tabular}{ll}
\hline \multicolumn{1}{c}{ Field Name } & \multicolumn{1}{c}{ Description } \\
\hline LICENSE_NUMBER & Well driller's license number \\
WELL\# & Well number assigned by driller \\
WRB\# & Water Resources Board ID \\
ELEV & Elevation of land surface \\
LATITUDE & Latitude \\
LONGITUDE & Longitude \\
LOCENT & Entity responsible for location \\
LOCACC & Estimate of the relative accuracy \\
FNAME & First name of well owner \\
LNAME & Last name of well owner \\
ST_NUMBER & Street number of well location \\
ROAD & Address of well location \\
ROAD2 & Additional information about well location \\
TOWN & Town in which well is located \\
MAP & Map page number \\
PARCEL & Parcel identifier \\
DCOMP & Date well was completed \\
USE & Reason for constructing well \\
REASON & Proposed use of well \\
TYPE & Type of well \\
TOTD & Total depth of well \\
BDKD & Depth to bedrock \\
CASING & Total length of casing \\
YTM & Yield-test method \\
YTD & Yield-test duration \\
YTQ & Discharge (yield) \\
SWL & Static water level \\
DMEAS & Date of measurement of static water level \\
OB & Type of overburden material \\
HYDRO_FRACT & Hydrofractured \\
HF_YIELD_BEFORE & Yield before hydrofractured \\
GROUTED & Grouted \\
NOTE & Special notes \\
\hline
\end{tabular}


Table 2. Types and sources of ancillary data tested in this study.

\begin{tabular}{ll}
\hline \multicolumn{1}{c}{ Data type } & \multicolumn{1}{c}{ Source } \\
\hline Population and housing density & U.S. Census Bureau, 2001, 2006 \\
$\begin{array}{l}\text { Monthly precipitation for Durham, Concord, and Portsmouth } \\
\text { Monthly base-flow discharge calculated from streamflow }\end{array}$ & National Climatic Data Center, 2009 \\
$\begin{array}{l}\text { Data on elevation, slope, aspect, curvature, and rate of change } \\
\text { of curvature from Digital Elevation Model }\end{array}$ & U.S. Geological Survey, 1993, 2004 \\
Geologic data & Robinson and Kapo, 2003 \\
\hline
\end{tabular}

\section{Statistical Analyses}

In this study, statistical methods were used to investigate water-level trends in bedrock wells. The analyses were done in three parts: 1) trend and distributional analysis of the well-completion data, 2) correlation and multiple-comparison test analysis of the data, particularly for relation to SWL, and 3) multiple regression analysis to identify factors that explain variance in the SWL data. Factors not included in the well-completion reports, such as climatic, geologic, and demographic variables, also were used in the analyses, for the wells with location information.

Kendall and seasonal Kendall tests were used to test for trends in SWL and other variables over the study period (Hirsch and Slack, 1984; Helsel and others, 2006). Spearman correlation analysis was used to indicate relations among the variables tested (Helsel and Hirsch, 1992; Helsel, 2005). A Spearman's rho of about 0.7 or higher (or -0.7 or lower) was considered indicative of a strong correlation. The nonparametric Wilcoxon (two-sample) and Kruskal-Wallis tests were used to compare distributions of data (Helsel and Hirsch, 1992; Helsel, 2005).

Multiple regression evaluates multiple variables simultaneously and was used to indicate which variables were the most significant predictors of SWL (Helsel and Hirsch, 1992). The model is of the form

$$
\ln (\mathrm{SWL})=\beta_{0}+\beta_{1}\left(X_{1}\right)+\beta_{2}\left(X_{2}\right) \ldots \beta_{\mathrm{n}}\left(X_{\mathrm{n}}\right)+E,
$$

where

$$
\begin{aligned}
& \ln (\mathrm{SWL})=\text { natural } \log \text { of the static water level, } \\
& \beta_{0}=\text { model intercept, } \\
& \beta_{1}-\beta_{\mathrm{n}}=\text { regression parameter estimates, } \\
& X_{1}-X_{\mathrm{n}}=\text { independent variables, and } \\
& E=\text { random error. }
\end{aligned}
$$

The SWL data are generally log-normally distributed. For nonparametric tests, the SWL data were rank-transformed prior to testing, whereas in the regression analyses, SWL data were log-transformed before analysis. A statistical test was considered significant when $p$-values were less than 0.05 . For the regression model, a parameter estimate was considered significant if the $p$-value was less than 0.05 . Regression model r-squared values of about 0.5 or higher were considered strong relations. All statistical tests and models were done with SAS System software (SAS Institute Inc., 2008).

Because of the large amount of data and their variability, the data were aggregated at various time scales. Aggregation of the data can reduce well-to-well variability in the larger data set (Nolan and Hitt, 2006); therefore, most analyses were done on data aggregated by year or by year and quarter. In this report, the first quarter of the year was January through March, the second quarter April through June, and so on. In this way, summary statistics for the variables were generated for each quarter for the period 1984-2007. Graphical representations of the data also were used and, in some cases, ordinary least-squares regression was used to indicate relations among graphed variables, with the regression equation and the coefficient of determination $\left(\mathrm{R}^{2}\right)$ values shown on the graphs (Helsel and Hirsch, 1992). Also, cubic spline lines were used on some graphs to portray seasonal patterns (SAS Institue, 1999). 


\section{Static Water Levels in Bedrock Wells in New Hampshire}

SWL data in the New Hampshire WWI represent one-time measurements of SWLs primarily in newly constructed wells, mostly within 3 days after the wells were constructed. More than 80 percent of SWL measurements were made on the day of construction. In many cases the SWL data values appear to have been rounded on the basis of several factors, such as measurement method, depth to water, and elapsed time between drilling and measurement; however, because of the large sample size, it is possible to see trends even in the data affected by rounding. Trends in the data were identified at yearly and quarterly aggregations of the SWL data.

The 10 most frequently reported values of SWL, well depth, bedrock depth, casing length, length of casing in bedrock, and yield for 56,437 wells in the New Hampshire WWI database between 1984 and 2007 are shown in table 3. It is notable that the 10 most frequently reported values of data for parameters such as SWL and total depth of well typically end in zero or five; these 10 values represent over 64 percent of the SWLs in the database. This coincidence indicates that some SWLs were estimated rather than directly measured. Historically, SWLs have been measured by a variety of methods including tapes, sonic indicators, wet marks on drilling rods, and by a method known as pebble drop (dropping a pebble and measuring the time until it hits the water surface) (R. Schofield, New Hampshire Department of Environmental Services, oral commun., 2010).

Some values for bedrock depth, casing length, length of casing in bedrock, and yield also appear to be rounded or estimated, but these values typically were obtained for wells drilled by equipment such as drill rods that are generally produced in even lengths. Thus, values for parameters related to drilling depth and casing are probably not rounded in the same way as SWL data. For casing length, anecdotal evidence indicates that depths ending in 1 are valid and may be related to the addition of a 1-ft drive shoe on the bottom of even-number intervals of casing. Also, many casing lengths were reported as even intervals, indicating that some lengths were reported with the drive shoe and some without, or that a drive shoe was not always used. Examination of yield data indicates that the most common values were rounded, and that low yields were reported without rounding. This would be expected, because the difference between 1 and $2 \mathrm{gal} / \mathrm{min}(3.8$ to $7.6 \mathrm{~L} / \mathrm{min})$ can be important in terms of reliable supply. Despite these limitations, the variability of data in the database is sufficient for SWL patterns related to common explanatory variables to be discerned from the aggregated data.

For yearly aggregated data, the mean SWL appears to have become deeper by about $13 \mathrm{ft}(4 \mathrm{~m})$ over the period 1984 to 2007 (fig. 2A). The reason for the apparent increase in the mean depth to SWL could be related to many possible factors, including increasing population (fig. 2B, C) and associated water use, well hydraulics, well construction, land use, and climate change. For example, the change in mean SWL could be related to new homes being built in settings such as hillsides or ridges, where SWLs can be somewhat deeper than in valley settings. Another hypothesis is that continued development and associated increases in water use, particularly for lawn watering, have resulted in lower water levels locally and regionally. Alternatively,

Table 3. Ten most frequently reported static-water levels, well depths, bedrock depths, casing lengths, lengths of casing in bedrock, and yields for 56,437 wells in the New Hampshire Department of Environmental Services database between 1984 and 2007.

\begin{tabular}{|c|c|c|c|c|c|c|c|c|c|c|c|}
\hline \multicolumn{2}{|c|}{$\begin{array}{l}\text { Static water level } \\
\text { (feet below } \\
\text { land surface) }\end{array}$} & \multicolumn{2}{|c|}{$\begin{array}{l}\text { Total well depth } \\
\text { (feet below } \\
\text { land surface) }\end{array}$} & \multicolumn{2}{|c|}{$\begin{array}{l}\text { Bedrock depth } \\
\text { (feet below } \\
\text { land surface) }\end{array}$} & \multicolumn{2}{|c|}{$\begin{array}{l}\text { Casing length } \\
\text { (feet) }\end{array}$} & \multicolumn{2}{|c|}{$\begin{array}{l}\text { Length of casing in } \\
\text { bedrock } \\
\text { (feet) }\end{array}$} & \multicolumn{2}{|c|}{$\begin{array}{c}\text { Yield } \\
\text { (gallons } \\
\text { per minute) }\end{array}$} \\
\hline Value & Percent & Value & Percent & Value & Percent & Value & Percent & Value & Percent & Value & Percent \\
\hline 20 & 16.3 & 300 & 4.5 & 10 & 7.0 & 20 & 16.0 & 10 & 8.6 & 20 & 7.5 \\
\hline 10 & 8.6 & 500 & 4.2 & 8 & 5.7 & 40 & 15.0 & 15 & 8.5 & 10 & 7.3 \\
\hline 30 & 8.3 & 305 & 3.7 & 5 & 4.4 & 21 & 5.3 & 12 & 7.2 & 5 & 6.8 \\
\hline 15 & 7.9 & 505 & 3.2 & 6 & 4.4 & 60 & 4.9 & 20 & 5.6 & 15 & 6.4 \\
\hline 25 & 5.7 & 400 & 3.2 & 15 & 4.0 & 30 & 3.9 & 14 & 5.1 & 4 & 6.0 \\
\hline 40 & 5.6 & 200 & 3.0 & 20 & 3.7 & 41 & 3.7 & 13 & 4.9 & 3 & 5.7 \\
\hline 0 & 3.9 & 420 & 2.6 & 4 & 3.5 & 42 & 2.9 & 16 & 4.9 & 6 & 5.5 \\
\hline 12 & 3.1 & 205 & 2.4 & 12 & 3.2 & 80 & 2.8 & 11 & 4.2 & 30 & 5.2 \\
\hline 5 & 2.5 & 220 & 2.3 & 30 & 2.7 & 50 & 1.9 & 17 & 3.5 & 2 & 5.1 \\
\hline 50 & 2.4 & 405 & 2.3 & 7 & 2.5 & 61 & 1.8 & 18 & 3.5 & 8 & 4.2 \\
\hline Total & 64.3 & & 31.4 & & 41.3 & & 58.2 & & 56 & & 59.7 \\
\hline
\end{tabular}



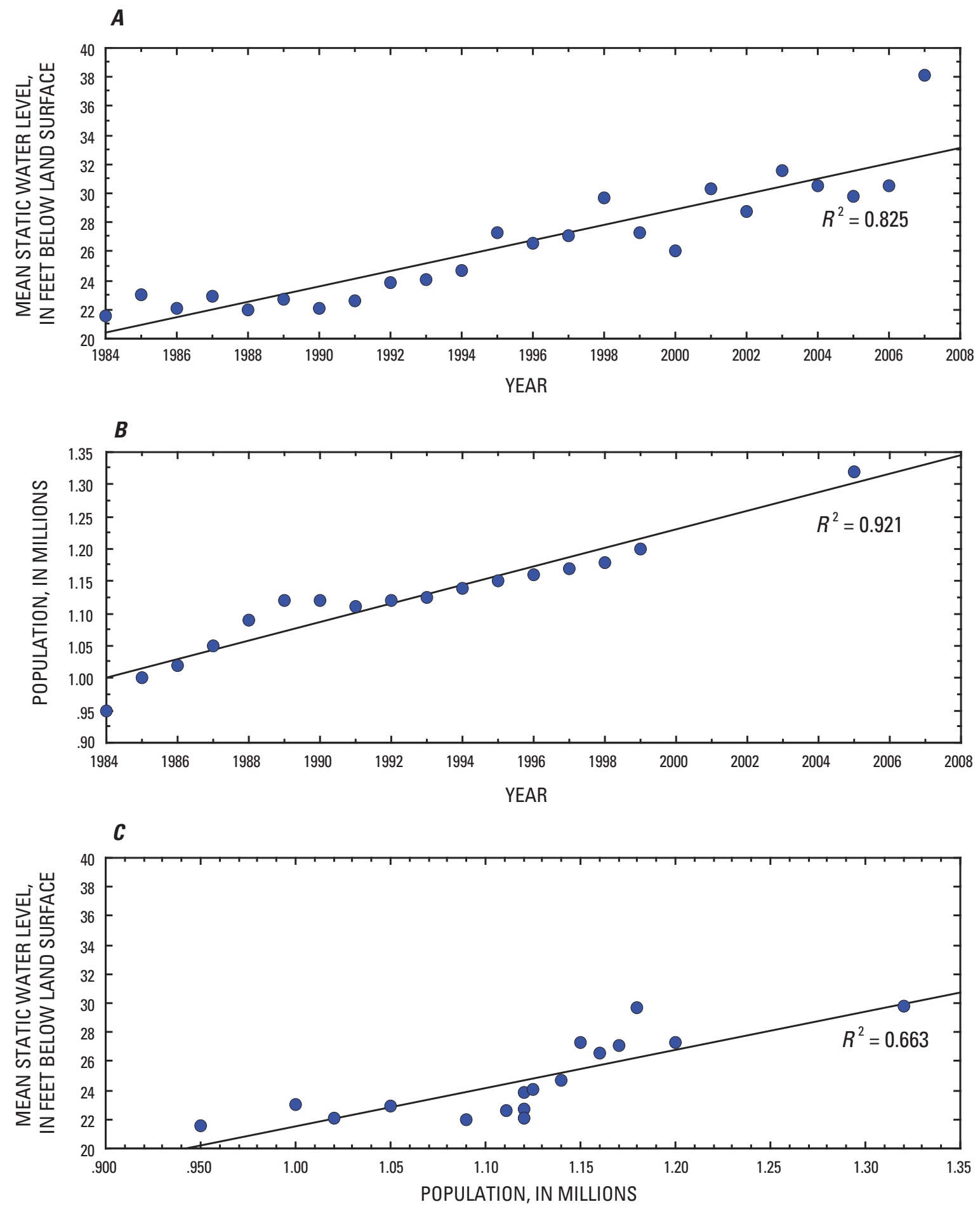

Figure 2. Graph showing A) mean static water level in bedrock wells in New Hampshire, 1984 through 2007; B) population in New Hampshire, 1984 through 2007; and C) mean static water level as a function of population. 
changes in drilling techniques with time, such as faster drilling rates or increased water-lifting capacity, may result in lower initial SWLs with no real change in water levels over longer periods. Also, increases in well depths may result in deeper SWLs, especially in groundwater-recharge zones, which likely occupy more land area than groundwater-discharge zones in New Hampshire.

Changes in SWL appear to relate to statewide population growth; that is, as population increases, so does the depth to SWL (fig. 2C); however, the complexity of bedrock-aquifer hydrology and population demographics creates much uncertainty in this relation. Factors such as where the population is distributed on the landscape, water use associated with the population, drilling practices, landscape features, specific geological formations, and the highly variable nature of fractured bedrock are all suspected of influencing the depth to SWL across New Hampshire.

SWL data were aggregated by year and quarter for the period 1984 to 2007 (24 yr), generating 96 mean aggregated SWL values. The smallest number of wells used to compute a mean quarterly SWL was 136, and the largest was 1,182. More than 90 percent of the mean quarterly values were based on more than 250 wells. Plotting the quarterly aggregated SWL shows that SWLs have become deeper with time and also that high and low SWLs have followed a seasonal cycle with generally greater depths to water during the summer-month growing season than during the winter nongrowing months (fig. 3). This pattern generally corresponds to the cycle of recharge over a year; mean quarterly SWLs in bedrock wells may reflect natural seasonal SWL variations. In a study in southeastern New Hampshire, typical bedrock SWLs varied seasonally by about 4 to $5 \mathrm{ft}$ above or below annual median values in the absence of withdrawal stresses (Mack, 2009), a pattern that is consistent with observed fluctuations in mean quarterly SWLs (fig. 3).

Based on the quarterly mean SWL data, Kendall's Tau was computed as a test of trend with time (Helsel and others, 2006). The test was also done as a seasonal Kendall, specifying two and four seasons. Both tests resulted in strong Tau values $(0.747$ and 0.692 , respectively) and adjusted p-values of less than 0.001 (table 4). Both show a trend slope of about $0.5 \mathrm{ft} / \mathrm{yr}(0.2 \mathrm{~m} / \mathrm{yr})$ per year of increased depth for the mean SWL.

\section{Relations among Static Water Levels, Precipitation, and Groundwater Recharge}

The amount, timing, form, and duration of precipitation affect the seasonal amount of groundwater recharge and ultimately SWLs. Average annual precipitation patterns from records from three stations in southern New Hampshire are shown on figure 4A. Kendall trend tests do not show trends in average annual precipitation over the time period of this study (for Durham, Kendall's tau $=0.019, p=0.9278$; for Portsmouth, Kendall's tau $=-0.038, p=0.8326$; and for Concord, Kendall's tau $=0.148, p=0.3648$ ). These results indicate that changes in precipitation may not be influencing the trends in SWL.

Estimates or indicators of recharge, however, rather than precipitation, may be better correlated to SWLs. Although groundwater recharge was not directly estimated for this study, groundwater-recharge patterns can be inferred from information on base flows from streams; base-flow patterns, in turn, can be indicative of patterns in water-table response in aquifers. Studies of base flow in the region, however, have noted small but not statistically significant third-quarter base-flow declines (Hodgkins and others, 2005). Furthermore, it is possible that shifts in the timing of peak flows in rivers in the region could be indicative of hydrologic changes that could affect SWLs (Hodgkins and Dudley, 2006).

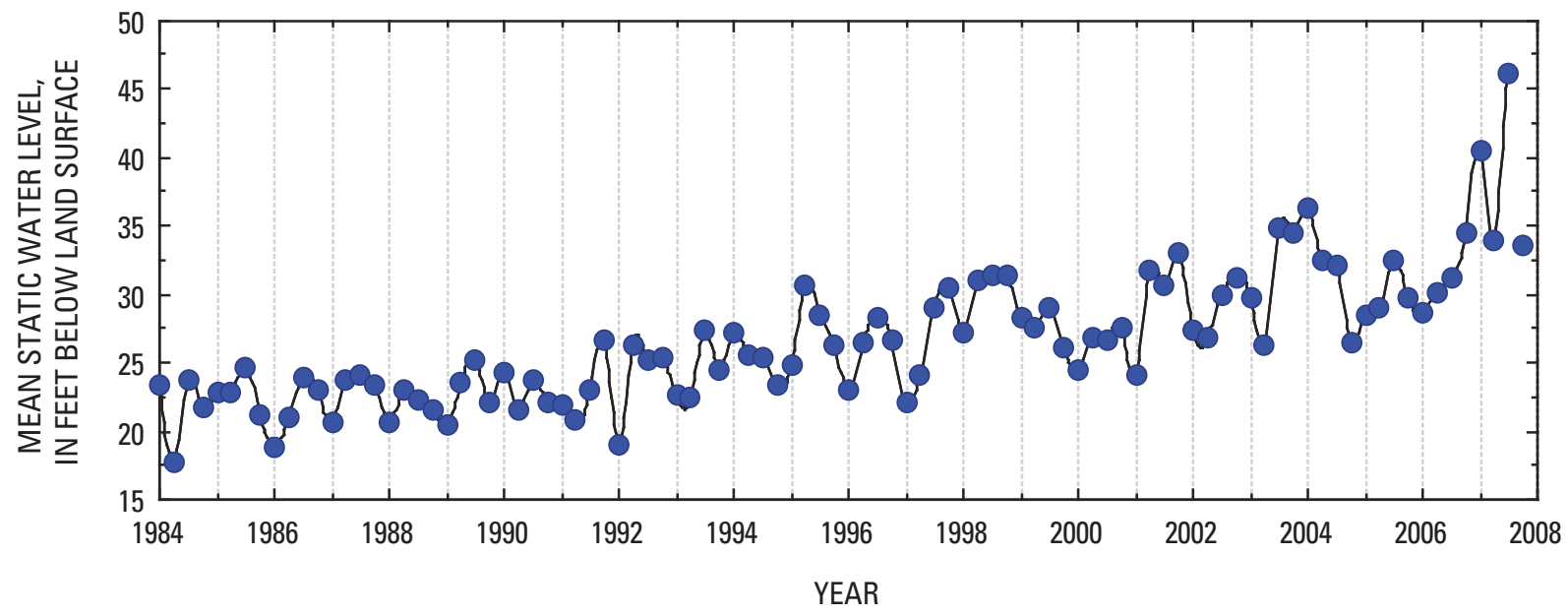

Figure 3. Graph showing mean quarterly static water levels in bedrock wells in New Hampshire, 1984 through 2007. 
Table 4. Summary of trend-test statistics for mean static water level and related well parameters aggregated by year and quarter from 1984-2007.

\begin{tabular}{|c|c|c|c|c|c|}
\hline $\begin{array}{l}\text { Variable aggregated } \\
\text { by year and quarter }\end{array}$ & $\begin{array}{c}\text { Number } \\
\text { of } \\
\text { years }\end{array}$ & $\begin{array}{l}\text { Number } \\
\text { of } \\
\text { seasons } \\
\text { used in } \\
\text { trend test }\end{array}$ & Kendall's Tau & $\begin{array}{l}\text { Adjusted } \\
p \text {-value }\end{array}$ & $\begin{array}{l}\text { Trend } \\
\text { slope }\end{array}$ \\
\hline \multicolumn{6}{|c|}{ Water-level data } \\
\hline Static water level & 24 & 4 & 0.692 & $<0.00001$ & 0.4766 \\
\hline \multicolumn{6}{|c|}{ Physical well properties } \\
\hline Total well depth & 24 & 4 & 0.828 & $<0.00001$ & 6.068 \\
\hline Casing length & 24 & 4 & 0.730 & $<0.00001$ & 0.8108 \\
\hline Length of casing in bedrock & 24 & 4 & 0.894 & $<0.00001$ & 0.5996 \\
\hline
\end{tabular}

Mean third-quarter base-flow estimates from Beaver Brook near North Pelham, the Oyster River near Durham, and the Soucook River near Concord are shown on figure 4B. Third-quarter values are shown because they are generally lower than base flows in other quarters and are representative of low-recharge conditions. If water levels were declining systematically, then it is possible that there would be corresponding declines in base flow, but this is not evident in the data shown in figure 4B.

Kendall trend tests on base-flow data indicate that there are no measurable trends over the time period tested. For Beaver Brook, for example, a Kendall trend test on third-quarter base flows indicates no significant trend (Kendall's tau $=-0.057$, $p=0.7398)$. Third-quarter data for the Oyster (Kendall's tau $=-0.058, p=0.7098)$ and Soucook Rivers $($ Kendall's tau $=0.105$, $p=0.5376)$ also showed no trend. Kendall trend tests on third-quarter SWLs, however, indicated deepening of SWLs over time in the Beaver Brook (Kendall's tau $=0.351, p=0.0241$ ) and Oyster River (Kendall's tau $=0.412, p=0.0235$ ) Basins but not in the Soucook River Basin (Kendall's tau $=0.052, p=0.7626$ ). The reason for the lack of similarity in trends of SWL and base flows in these three watersheds is unclear.

Aggregated mean quarterly SWLs regressed against year have a relatively similar slope, but the intercepts for the four quarters differ (fig. 4C). The depth to mean SWL is largest (deeper water levels) for quarter 3 and smallest for quarter 1. These regression lines indicate that, whereas the trend with time (slope) is the same for each quarter, the magnitude of the effect varies by season. This result implies that the season when a well is drilled may be a significant explanatory factor for variation in SWLs.

Mean quarterly precipitation in the three watersheds in southern New Hampshire did not vary over time for quarters 2 , 3 , and 4 but generally was lowest in quarter 1 (fig. 5A). Base-flow estimates and SWLs across the state do vary by season, however. Boxplots of the distributions of base flow by quarter (data only for the Oyster River are shown) show that recharge was lowest in quarter 3 and greatest in quarters 1 and 2 (fig. 5B). Correspondingly, mean SWLs were deepest in quarter 3 and shallowest in quarter 1 (fig. 5C). This shows that SWLs are deepest primarily during periods of low recharge.

\section{Relation of Static Water Levels to Well-Construction Parameters}

Mean quarterly SWLs in bedrock wells were increasing (becoming deeper) over time, as were many other well parameters for the period 1984 to 2007. Previous studies found that well depths in New Hampshire also have been increasing with time (Chormann, 1990; Drew and others, 2001; Moore and others, 2002). The increase in well depth, in at least one study, has been attributed to increasing demand (Moore and others, 2002), which was met in part by increases in borehole storage provided by deeper wells. Between 1984 and 2007, the average depth of bedrock wells in the database increased by approximately $140 \mathrm{ft}$ (43 m) (fig. 6A). In addition to increases in water demand, however, other factors also could explain the apparent increase in depth. These factors include improved drilling techniques, faster drilling equipment, and a desire for increased protection against wells going dry during droughts or periods of high-intensity use. 

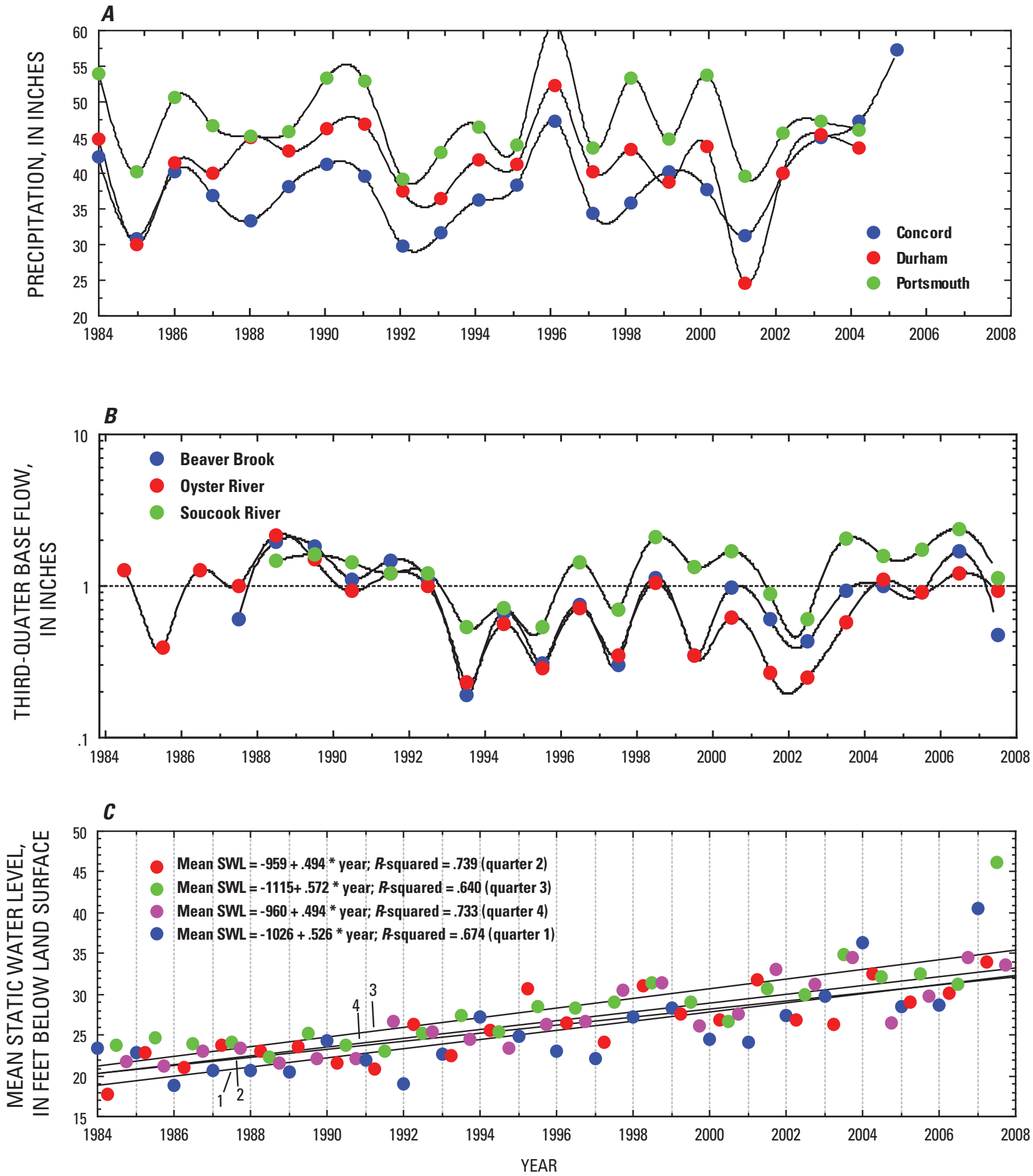

Figure 4. Graphs showing A) Mean annual precipitation at Portsmouth, Durham, and Concord, New Hampshire, 1984-2005; B) third-quarter base flow at Beaver Brook, Oyster River, and Soucook River; and C) mean quarterly static water levels, 1984-2007. 

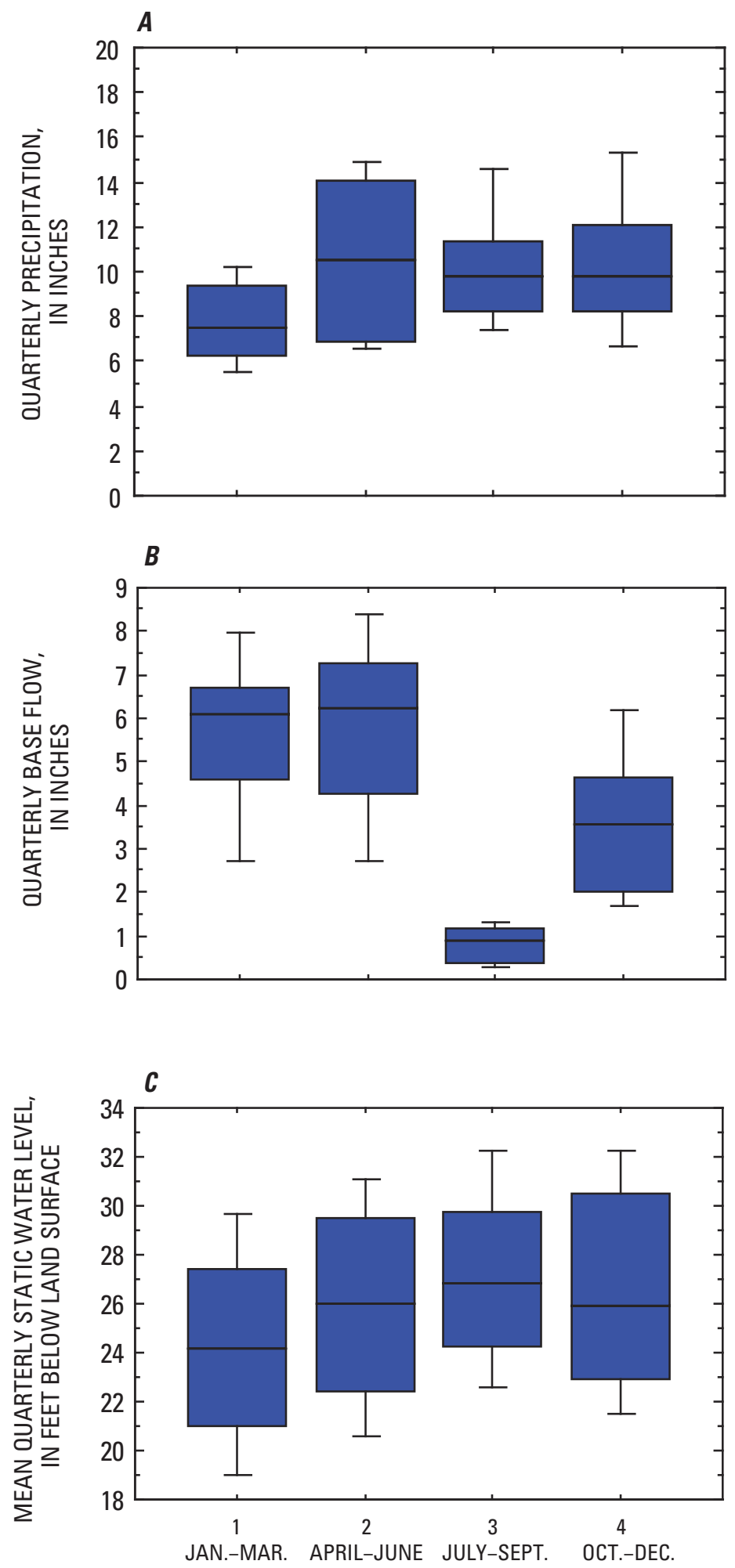

EXPLANATION

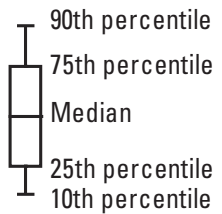

Figure 5. Boxplots summarizing A) quarterly precipitation at Concord Municipal Airport; B) quarterly base flow at Oyster River, near Durham, NH (01073000); and C) mean quarterly static water level statewide by quarter, 1984- 2007. 

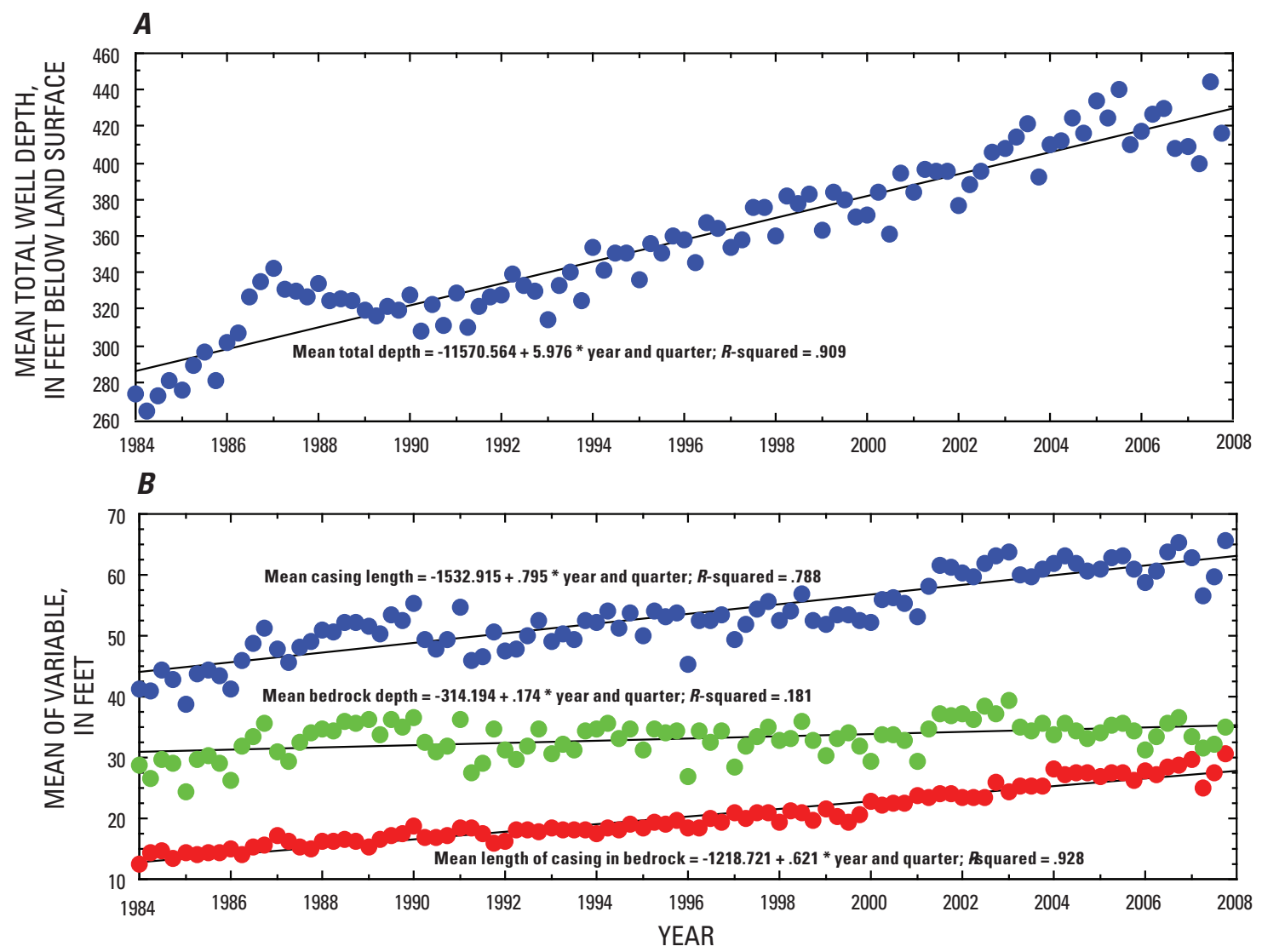

EXPLANATION

- Mean casing length, in feet

- Mean length of casing in bedrock, in feet

- Mean bedrock depth, in feet below land surface
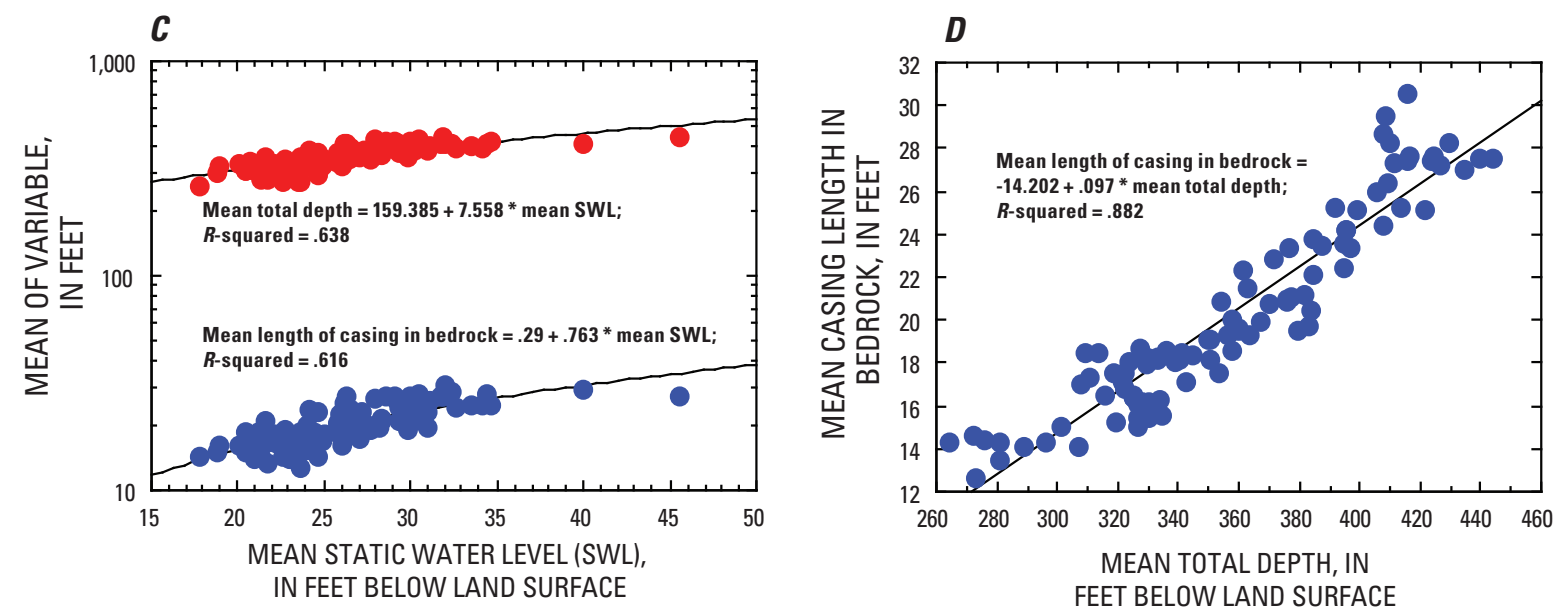

EXPLANATION

- Mean length of casing in bedrock, in feet

- Mean total depth, in feet below land surface

Figure 6. Graphs showing A) mean total well depth by year and quarter; B) mean casing length, mean length of casing in bedrock, and mean bedrock depth by year and quarter; $\mathrm{C}$ ) mean total well depth and mean length of casing in bedrock as a function of mean static water level; and D) mean length of casing in bedrock as a function of mean total well depth. 


\section{Total Depth, Casing Length, and Length of Casing in Bedrock}

Total depth, casing length, and casing length in the bedrock show strong trends with time. The slopes of these trends indicate that mean well depths increased at about $6 \mathrm{ft} / \mathrm{yr}(2 \mathrm{~m} / \mathrm{yr})$, and casing length and casing length in bedrock increased by about $0.8 \mathrm{ft} / \mathrm{yr}(0.24 \mathrm{~m} / \mathrm{yr})$ and $0.6 \mathrm{ft} / \mathrm{yr}(0.18 \mathrm{~m} / \mathrm{yr})$, respectively (table 4$)$. Total depth, casing length, and length of casing in bedrock were correlated with each other (table 5). SWL also was correlated strongly with these well-construction factors (rho $=0.83$ to $0.86, p<0.0001)$ and with year measured, indicating the possibility that any of these factors could explain the apparent deepening of SWLs (table 5). The length of casing in bedrock has increased, although the regulatory casing-length requirement did not change during the study period. Improved awareness that additional casing in bedrock may help to protect well water from potential surface contaminants, as well as driller-education programs, may be partly responsible for the increase in casing length (Richard Schofield, New Hampshire Department of Environmental Services, oral commun., 2008).

Graphs of the well-construction data provide additional information about the relations among these variables. The lengths of casing and casing in bedrock increased significantly over the study period (fig. 6B); however, the mean bedrock depth, which is equivalent to the length of casing minus the length of casing in bedrock, has increased only slightly (fig. 6B). This comparison indicates that the apparent increases in casing length over time were primarily a result of a desire to increase the length of casing in bedrock. Mean total well depth has also increased substantially over time (fig. 6A). The combination of potentially lower heads at deeper aquifer depths coupled with a potentially diminishing proportion of water from overburden and near-surface fractures (as a result of a proportionally greater length of casing in bedrock) may result in deeper SWLs in bedrock wells. Mean total depth and mean length of casing length in bedrock are strongly related to mean SWL (fig. 6C). That both of

Table 5. Spearman rank correlation coefficients for mean static water level and means of selected physical and hydraulic parameters by year and quarter, 1984-2007 $(n=96)$.

[Elapsed time is the time between completion of the well and measurement of the static water level. $<$ less than; --, not applicable]

\begin{tabular}{|c|c|c|c|c|c|c|c|c|}
\hline $\begin{array}{c}\text { Mean } \\
\text { of } \\
\text { variable }\end{array}$ & Statistic & $\begin{array}{c}\text { Year } \\
\text { measured }\end{array}$ & $\begin{array}{l}\text { Total } \\
\text { depth }\end{array}$ & $\begin{array}{l}\text { Casing } \\
\text { length }\end{array}$ & $\begin{array}{l}\text { Length of } \\
\text { casing } \\
\text { in rock }\end{array}$ & $\begin{array}{c}\text { Yield, } \\
\text { reported }\end{array}$ & $\begin{array}{l}\text { Static } \\
\text { water } \\
\text { level }\end{array}$ & $\begin{array}{c}\text { Elapsed } \\
\text { time }\end{array}$ \\
\hline \multirow[t]{2}{*}{ Year measured } & Rho & 1 & 0.9502 & 0.8688 & 0.9765 & 0.4929 & 0.8397 & 0.2951 \\
\hline & p-value & -- & $<0.0001$ & $<0.0001$ & $<0.0001$ & $<0.0001$ & $<0.0001$ & 0.0035 \\
\hline \multirow[t]{2}{*}{ Casing length } & Rho & 0.8688 & 0.8839 & 1 & 0.8941 & 0.3799 & 0.8358 & 0.2614 \\
\hline & p-value & $<0.0001$ & $<0.0001$ & -- & $<0.0001$ & 0.0004 & $<0.0001$ & 0.0101 \\
\hline \multirow[t]{2}{*}{ Reported yield, } & Rho & 0.4929 & 0.4780 & 0.3799 & 0.4617 & 1 & 0.5063 & 0.1051 \\
\hline & p-value & $<0.0001$ & $<0.0001$ & 0.0004 & $<0.0001$ & -- & $<0.0001$ & 0.3083 \\
\hline \multirow[t]{2}{*}{ Static water level } & Rho & 0.8397 & 0.8639 & 0.8358 & 0.8290 & 0.5063 & 1 & 0.2645 \\
\hline & p-value & $<0.0001$ & $<0.0001$ & $<0.0001$ & $<0.0001$ & $<0.0001$ & -- & 0.0092 \\
\hline \multirow[t]{2}{*}{ Elapsed time } & Rho & 0.2951 & 0.2747 & 0.2614 & 0.2931 & 0.1051 & 0.2645 & 1 \\
\hline & p-value & 0.0035 & 0.0068 & 0.0101 & 0.0038 & 0.3083 & 0.0092 & -- \\
\hline
\end{tabular}


these factors are increasing over time indicates that they could potentially be responsible for the apparent concurrent deepening of SWL. Thus, in this analysis, well-construction variables function as variables related to time. One difficulty, however, in assessing the relative effect of these variables on SWL is that the variables themselves are strongly correlated (illustrated by an example in fig. 6D). Thus it is possible that either factor or both could contribute to the observed trend in SWLs.

Whereas SWLs have become deeper over time, the mean total well depth also has increased over time. Mean total well depth increased by about $140 \mathrm{ft}(43 \mathrm{~m})$ from 1984 to 2007 (fig. 6A) and the mean depth to SWL increased by about $13 \mathrm{ft}(4 \mathrm{~m})$ (fig. 2A). The net result is that the length of the water column in bedrock wells also has increased, leaving well owners with, on average, about $130 \mathrm{ft}(40 \mathrm{~m})$ more water (fig. 7), or about 200 gal $(750 \mathrm{~L})$ in a 6-in.-diameter $(0.15$-m) bedrock well under static (nonpumping) conditions. The amount of water in the borehole (wellbore storage) may not be a significant concern for high-yielding wells, but for wells with low yields (especially relative to common domestic-well pumping rates), the amount of the additional water in borehole storage is potentially significant; more water can be used for domestic purposes with a lower probability that the well might go dry. In addition, more water may be used because it is available, possibly adding to the problem of local well interference — where adjacent wells influence the availability of water to the well—or exacerbating drought-related well problems.

The length of casing in bedrock and the type of casing seal may limit the connectivity of the bedrock aquifer with the overburden aquifer. Casings seals can be formed by installing a drive shoe on the end of the casing and hammering the casing a few feet into the bedrock borehole. The void area outside the casing can be filled with cement, bentonite grout, or cuttings generated by the drilling process. Grout seals are required for wells that do not conform to siting requirements (R. Schofield, New Hampshire Department of Environmental Services, oral commun., 2010). The use of cement or bentonite grout may provide added protection against water entering the well from unconsolidated materials above the bedrock. Grout seals could have an effect on water levels in wells if they sealed out unconsolidated aquifer water from the bedrock well and reduced the hydraulic connection between the unconsolidated aquifer and the bedrock aquifer. Consistent reporting of grout seals appears in the WWI database by about 1999; as a result, analyses of the effects of grout on SWLs excluded data added prior to 1999. Correlations between SWLs for wells with grout seals and well-construction parameters are poorer than the correlations between SWLs for wells without grout seals and the same parameters (table 6). This result may imply that hydraulic connections between the bedrock and overburden aquifers are minimized by a grouted seal; conversely, the absence of a grout seal may allow better hydraulic connection between the bedrock and overburden. The lack of a correlation between SWLs and elapsed time (time elapsed between well construction and SWL measurement), particularly for wells without grouted seals, may be a further indication of hydraulic connection with the overburden flow system.

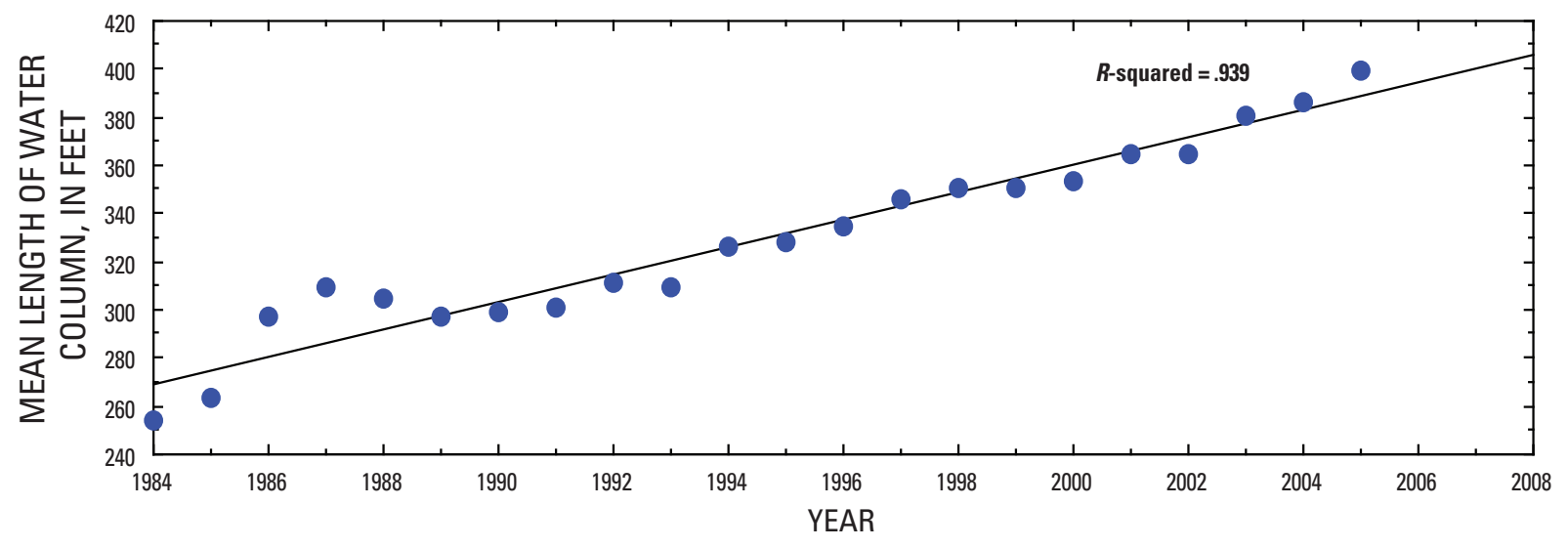

Figure 7. Graphs showing mean length of water column in bedrock wells in New Hampshire, 1984 through 2007 
Table 6. Correlation of mean static water level with year measured, mean total depth, casing length, length of casing in bedrock, elapsed time, and yield, for grouted and nongrouted wells by year and quarter, 1999-2007 ( $n=36)$.

[Elapsed time is the time between completion of the well and measurement of the static water level]

\begin{tabular}{lllllll}
\hline $\begin{array}{l}\text { Mean static } \\
\text { water level }\end{array}$ & $\begin{array}{l}\text { Mean of } \\
\text { variable, } \\
\text { by year and } \\
\text { quarter }\end{array}$ & Year & $\begin{array}{c}\text { Total } \\
\text { depth }\end{array}$ & $\begin{array}{c}\text { Casing } \\
\text { length }\end{array}$ & $\begin{array}{c}\text { Length of } \\
\text { casing in } \\
\text { bedrock }\end{array}$ & $\begin{array}{c}\text { Elapsed } \\
\text { time }\end{array}$ \\
\hline Grouted & Rho & 0.4733 & 0.2013 & 0.3346 & 0.4834 & 0.2489 \\
& p-value & 0.0036 & 0.2391 & 0.0461 & 0.0028 & 0.1432 \\
Nongrouted & Rho & 0.5323 & 0.4420 & 0.5493 & 0.5076 & 0.1115 \\
& p-value & 0.0008 & 0.0070 & 0.0005 & 0.0016 & 0.5175 \\
\hline
\end{tabular}

\section{Elapsed Time and Yield}

The SWL data were assessed to determine if depth to SWL may be influenced by time between well construction and measurement of the SWL (elapsed time). During the construction of a well, water is added or removed from the well as a result of the drilling process. The depth to SWL can change after drilling as the well becomes equilibrated to natural waterlevel conditions in the aquifer. The time required to reach equilibrium depends strongly on well hydraulics. Most (more than 80 percent) of the SWLs in the NHDES database were measured within 3 days of well completion, with more than 98 percent measured within 30 days of well completion. Analysis of subsets of SWLs defined by ranges of elapsed time revealed differences in the strengths of correlation coefficients between SWL and other variables. Elapsed time was categorized as 0 to 3 days and 3 to 30 days, and boxplots of the year-and-quarter-aggregated data show that there are differences between the distributions of data for several parameters. SWLs are generally deeper in wells with larger elapsed times between construction and SWL measurement (fig. 8A) as well as with total depth, casing length, and bedrock depth (figs. 8B, C, and E), although the mean length of casing in bedrock is not significantly different (fig. 8D). Wells with larger elapsed times were more likely to be deeper and have lower yields (fig. 8F). The combination of deeper wells and lower yields in the longer elapsed-time group indicates that SWLs can be lower than expected for deep low-yielding wells.

Correlation coefficients for SWL and selected parameters for the two categories of elapsed time shown in table 7 indicate that the correlation between SWL and most variables decreases with greater elapsed time. Although mean SWL remains correlated with year for the 3-to-30-day elapsed-time category, the strength of the correlation is weaker than the correlation between SWL and year for the 0-to-3-day elapsed-time category. Also noteworthy is the reduction in the magnitude of the correlation coefficient with casing length and yield. This can be interpreted to mean that wells with longer elapsed times also are low-yield wells and that SWLs need long recovery times in order for the SWL to be representative.

\section{Hillslope Effects}

The position of a well relative to the topography of the surrounding land can influence the SWL in a well. A simplified metric was used to indicate the position of each well with respect to surrounding topography in order to assess hillslope effects. By using data from 24,000-scale DEMs (100-ft (30-m) grid spacing) (U.S. Geological Survey, 2004), the elevation of the well and the minimum elevation of the land surface within a 1,640-ft (500-m) radius around the well was determined. These data were used to compute the height of the well above that minimum elevation, termed height above valley bottom (HAVB). The median HAVB of all statewide data was about $66 \mathrm{ft}(20 \mathrm{~m})$, and the 25 th- and 75 th- percentile values were about $33 \mathrm{ft}(10 \mathrm{~m})$ and $100 \mathrm{ft}(30 \mathrm{~m})$, respectively. For the analysis of well factors shown in fig. 9, the data for HAVB were divided into categories of less than $66 \mathrm{ft}(20 \mathrm{~m})$ and greater than or equal to $66 \mathrm{ft}$.

Mean SWL and mean total well depth were significantly deeper in wells with a HAVB greater than or equal to $66 \mathrm{ft}(20 \mathrm{~m})$ than in wells in areas of lower relief (HAVB less than $66 \mathrm{ft}(20 \mathrm{~m})$ ) (fig. 9A, B). Mean values for casing length, length of casing in bedrock, and bedrock depth, however, were not different for the two HAVB groups (figs. 9C, D, and E). Mean well yield was significantly less (fig. 9F) in the higher HAVB category. 

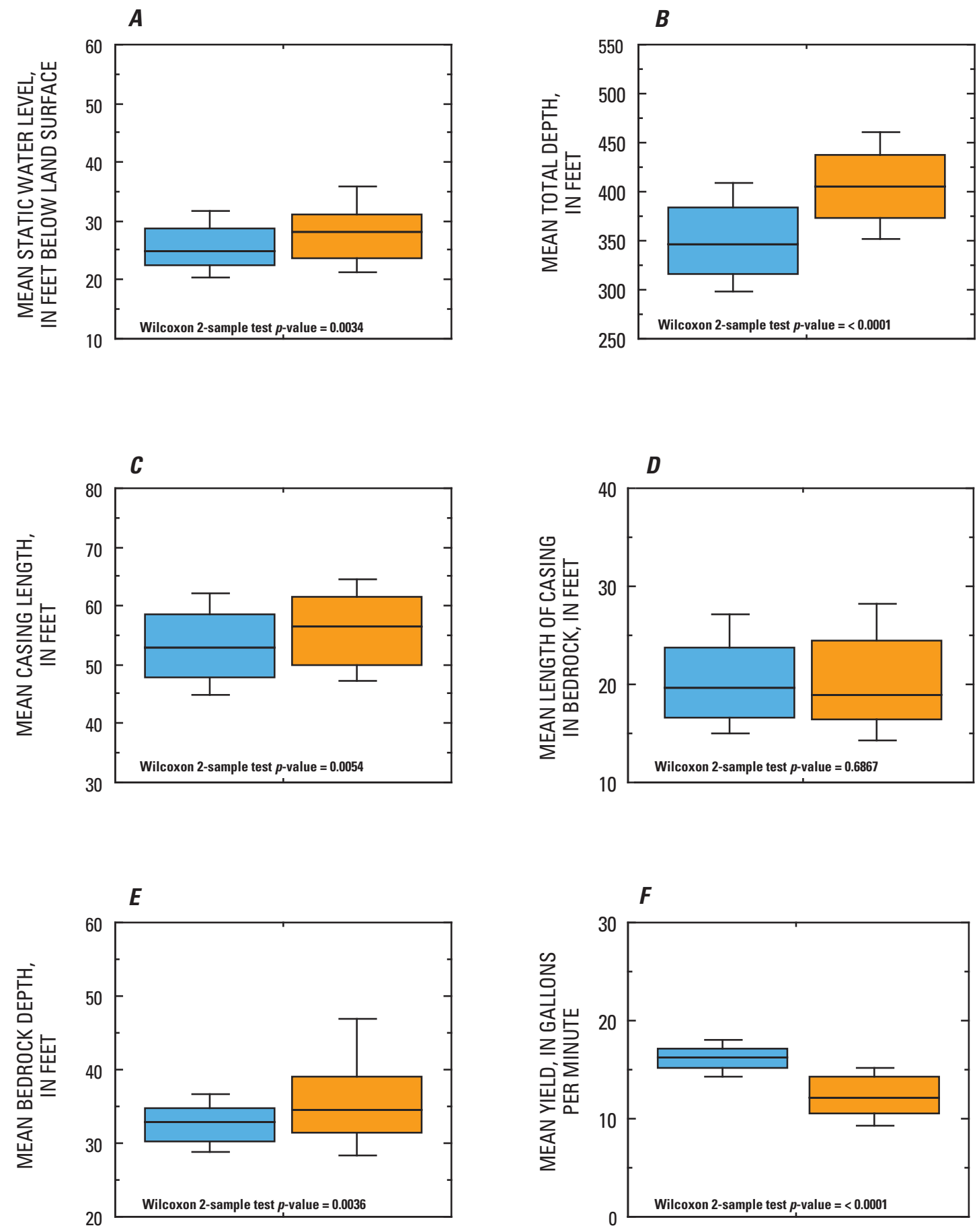

\section{EXPLANATION}

Less than 3 days between construction and static water-level measurement

Greater than 3 to 30 days between construction and static water-level measurement

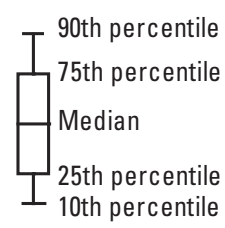

Figure 8. Boxplots summarizing A) mean static water level, B) mean total well depth, C) mean casing length, D) mean length of casing in bedrock, E) mean bedrock depth, and F) mean reported yield, for categories of elapsed time between well construction and static water-level measurement. 
Table 7. Correlation of mean static water level with year measured, mean total depth, casing length, length of casing in bedrock, elapsed time, and yield for categories of elapsed time between construction and measurement of static water level; aggregated by year and quarter, 1984-2007 $(n=96)$.

[The number of wells before aggregation was 46,184 for 0 to 3 days (d) and 9,019 for 3 to $30 \mathrm{~d}$. $\mathrm{N}$ for correlates is variable; elapsed time is the time between completion of the well and measurement of the static water level. $<$, less than]

\begin{tabular}{llcrrrrr}
\hline $\begin{array}{l}\text { Mean static } \\
\text { water level }\end{array}$ & $\begin{array}{c}\text { Mean of } \\
\text { variable, } \\
\text { by year and } \\
\text { quarter }\end{array}$ & Year & Total depth & Casing length & $\begin{array}{c}\text { Length of } \\
\text { casing in } \\
\text { bedrock }\end{array}$ & Elapsed time & Yield \\
\hline 0 to $3 \mathrm{~d}$ & $\begin{array}{l}\text { Rho } \\
\text { p-value }\end{array}$ & 0.8050 & 0.8262 & 0.8082 & 0.7932 & 0.4214 & 0.5427 \\
& $<0.0001$ & $<0.0001$ & $<0.0001$ & $<0.0001$ & $<0.0001$ & $<0.0001$ \\
3 to 30 d & Rho & 0.5688 & 0.6571 & 0.3204 & 0.6177 & -0.3427 & 0.1639 \\
& p-value & $<0.0001$ & $<0.0001$ & 0.0015 & $<0.0001$ & $<0.0006$ & 0.1106 \\
\hline
\end{tabular}

These results indicate that for the wells on higher, steeper, or more irregular hillslopes, SWLs have a greater likelihood of being significantly deeper than their lower-HAVB counterparts. The corresponding lower yields for these wells may mean a reduced capacity to recover after pumping and a greater susceptibility to drought conditions than wells with lower values of HAVB. It is possible that drilling high-HAVB wells even deeper might reduce the potential for problems associated with drought or high-use periods.

Hillslope position data indicate that there may be a trend with time; for example, there are observable short-term increases in the magnitudes of these factors followed by declines and subsequent increases from about 1995 to 2007. To illustrate this, mean elevation, mean slope, and mean HAVB are shown as functions of time for the periods 1984 through 1995 and 1995 through 2007 (fig. 10). These graphs indicate that all three factors are increasing over time for the latter period of data (1995-2007). In general, there is an inverse trend with time in the first half of the data (1984-1994), although the relations are generally weaker and less significant than the positive relations in the latter half of the data (fig. 10). These observations indicate that, similar to well depth and length of casing in bedrock, hillslope factors are also time dependent. In this way, many of the physical well factors are surrogates for time and are thus, in part, trend variables. It is not clear, however, which variables are controlling the increase in depth to SWLs.

\section{Multiple Regression Analysis of Static Water Levels}

Multiple regression analysis was used to examine the relative influence of numerous variables on aggregated SWL data statewide. The dependent variable was mean of the log of SWL by year and quarter. Independent variables consisted of all physical information about the wells (table 1) and data derived from GIS variables, including precipitation, recharge, digital elevation model and its derivative information, seasonal indicators, and geologic variables. Several models were developed, initially by stepwise regression methods, and then manually.

The aggregated SWL data were first stratified by major geologic type (igneous or metamorphic rock) because Wilcoxon tests indicated that there were significant differences between the distributions of the SWL data by these major geologic types (table 8). Most SWL and well-construction parameters were greater in magnitude for the igneous-rock wells than for the metamorphic-rock wells. Multiple regression models were then run separately for wells in igneous and metamorphic rocks to determine the independent variables and parameter estimates by major rock type (table 9).

Standardized parameter estimates also were calculated for the multiple regression models. Standardized estimates for a variable indicate the effect of change of one standard deviation in that variable and thus can be used to compare the relative effects of the variables (Menard, 2002).

Mean total depth was strongly related to mean log SWL in both models (table 9); both measures indicated increasing depth over time. This result is consistent with common hydrologic conditions in aquifers in recharge areas where water in the upper aquifer flows toward deeper parts of the aquifer in response to hydraulic gradient. In order for recharge to occur, hydraulic head (indicated by water level) must be lower in deeper parts of the aquifer than in shallow parts. Thus, one explanation for 

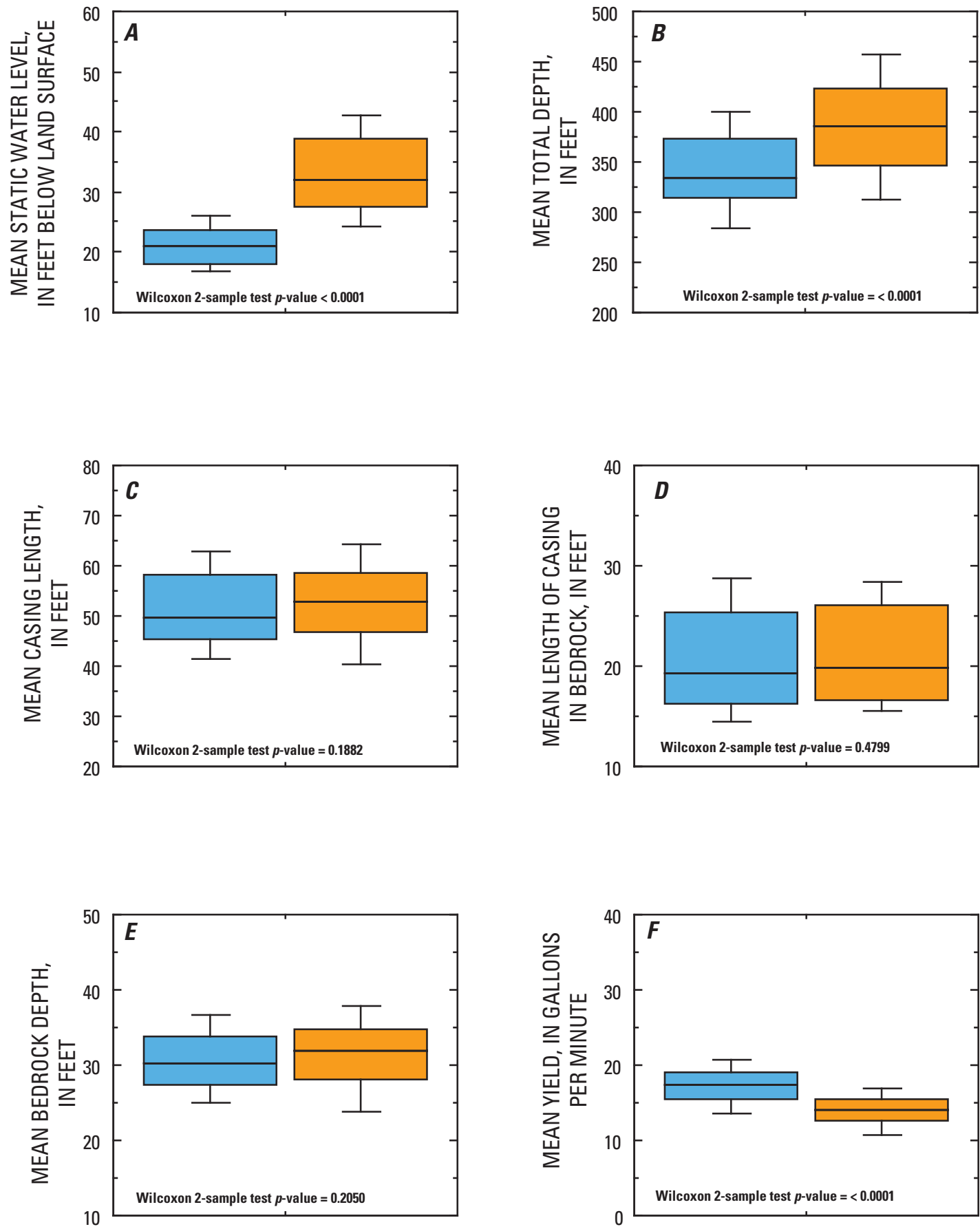

\section{EXPLANATION}

Height of land surface at well, above minimum elevation within a 1,640 -foot $(500$-meter) radius of the well

$\square$ Less than 66 feet (20 meters) above minimum elevation

$\square$ Greater than or equal to 66 feet ( 20 meters) above minimum elevation

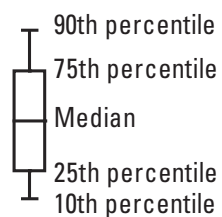

Figure 9. Boxplots summarizing A) mean static water level, B) mean total well depth, C) mean casing length, D) mean length of casing in bedrock, E) mean bedrock depth, and F) mean reported yield, for categories of height above the minimum elevation within a 1,640-foot (500-meter) radius. 

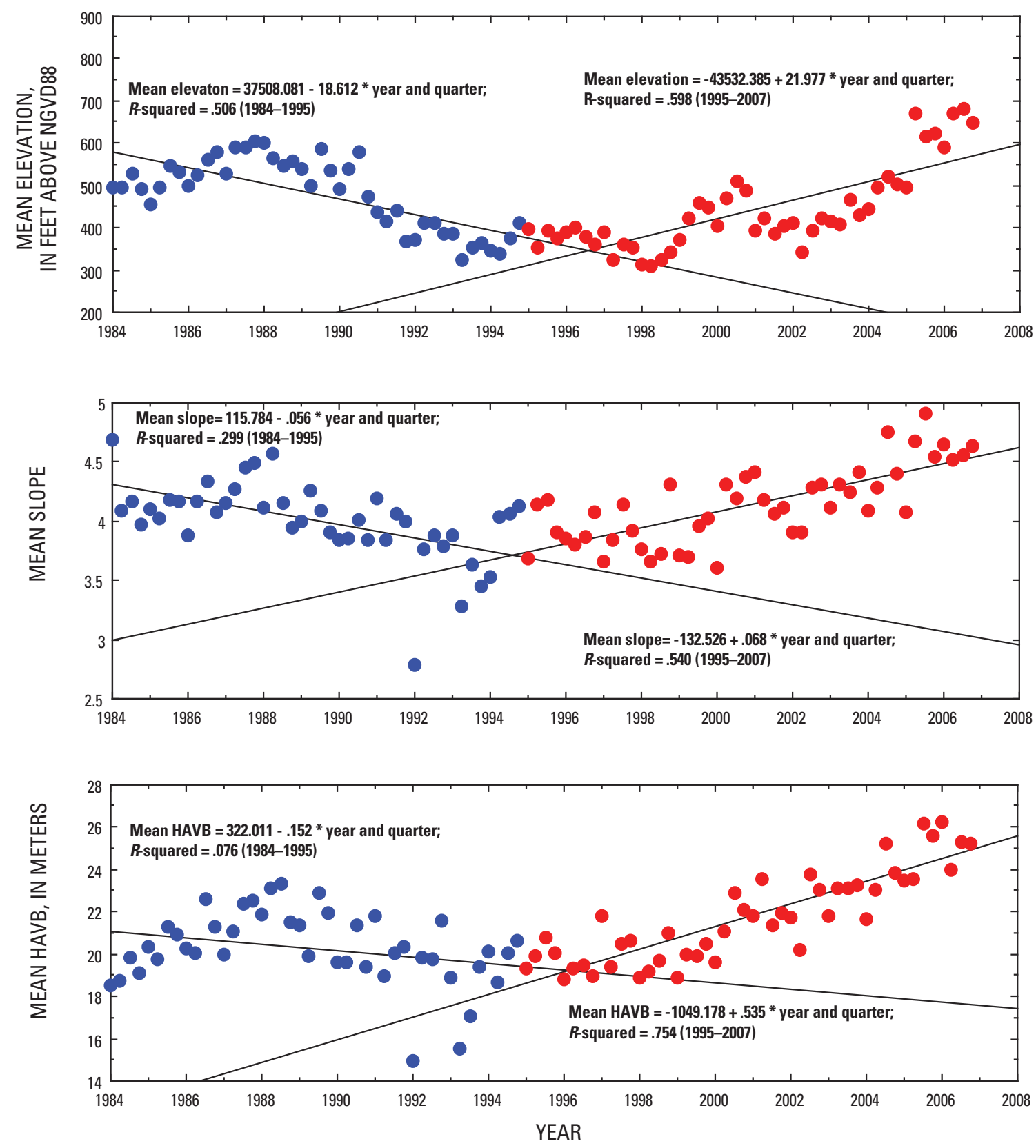

EXPLANATION

- 1984-1995

- 1995-2007

Figure 10. Graphs showing mean elevation of well, mean slope at the well, and mean height above minimum elevation within 1,640-foot (500-meter) radius of well (HAVB) by year and quarter, 1984-2007. 
Table 8. Comparison of mean quarterly values of selected variables for wells in igneous and metamorphic rocks.

[The letter A under Major rock group indicates that the distribution of the data for that variable is greater in magnitude than if it has the letter B; $p$-value indicates significance at the 95 -percent confidence interval]

\begin{tabular}{|c|c|c|c|}
\hline \multirow[b]{2}{*}{ Variable } & \multicolumn{2}{|c|}{ Major rock group } & \multirow{2}{*}{$\begin{array}{c}p \text {-value } \\
\text { two-sample } \\
\text { test }\end{array}$} \\
\hline & Igneous & Metamorphic & \\
\hline Static water level & A & $\mathrm{B}$ & $<0.0001$ \\
\hline Total depth & A & $\mathrm{B}$ & $<0.0001$ \\
\hline Bedrock depth & A & $\mathrm{B}$ & 0.0001 \\
\hline Casing length & A & $\mathrm{B}$ & 0.0015 \\
\hline Casing length in bedrock & A & A & 0.1535 \\
\hline Yield & $\mathrm{B}$ & A & 0.0066 \\
\hline Curvature (rate of change of slope) & A & $\mathrm{B}$ & 0.0474 \\
\hline Slope & A & $\mathrm{B}$ & $<0.0001$ \\
\hline $\begin{array}{l}\text { Height above minimum elevation } \\
\text { within a } 1,640 \text {-foot ( } 500 \text {-meter) } \\
\text { radius of well }\end{array}$ & A & $\mathrm{B}$ & $<0.0001$ \\
\hline Elevation & A & $\mathrm{B}$ & $<0.0001$ \\
\hline
\end{tabular}

Table 9. Multiple regression models on the means of logarithms of static water levels by major rock type in New Hampshire.

$\left[\mathrm{R}^{2}\right.$, adjusted values of coefficient of determination; Dim., dimensionless; $<$, less than; --, not applicable; $p$-value indicates significance at the 95 -percent confidence interval]

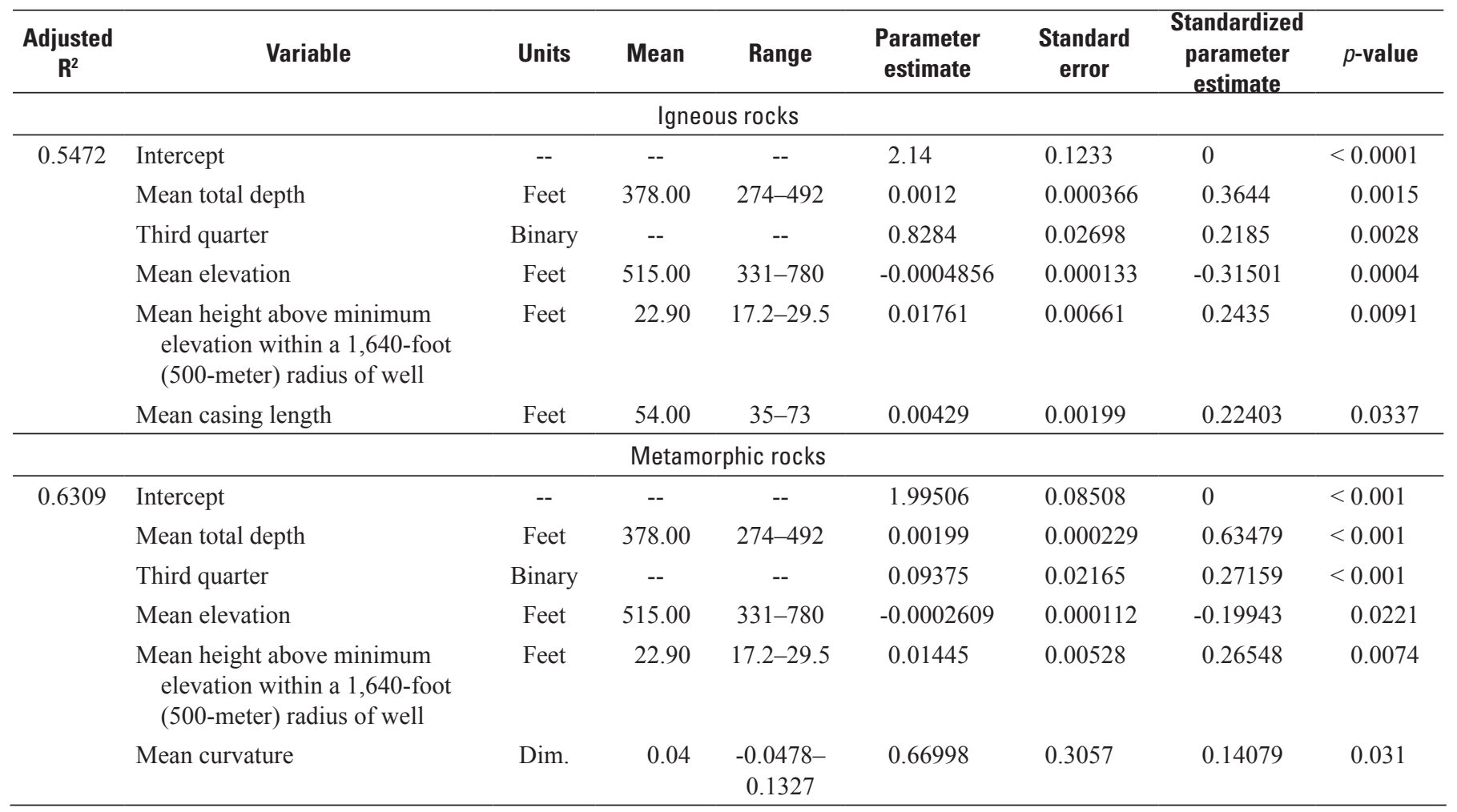


the relation is that, as well depth increases, the likelihood of encountering deeper water levels also increases. Variations in vertical flow gradients calculated by groundwater-flow models for bedrock aquifers in coastal New Hampshire indicate that gradients may not be sufficiently large to explain the SWL declines observed in this study (Mack, 2009); however, vertical gradients derived from flow models are not generally representative of gradients at individual wells. Another explanation is that because SWLs in wells are limited by the depth of the well (measured SWLs cannot exceed the well depth), deeper SWLs are increasingly possible because wells have become deeper over time.

Season (third quarter) was also a significant variable in both models. Quarter 3, which corresponds to July through September, was associated with deeper water levels. Recharge is also at its lowest magnitude at this time (fig. 5A), probably owing to maximum evapotranspiration during the summer growing season. Thus, low-recharge periods are related to deeper SWLs.

As previously noted, larger HAVB values were related to deeper SWLs in wells. Mean elevation was a significant predictor of mean SWL in both igneous and metamorphic rocks, and, along with HAVB, may account for the general effects of topography and hillslope position. The elevation variable has a negative coefficient and may be reflective of higher precipitation with higher elevations.

To determine if the statewide models reflect the general character of potential controlling factors, models were generated for each county in the state. The results for county-level models (not shown) were similar to those of the statewide modelsthat is, mean total depth is the primary regressor. For the county models, season and hillslope position were also related to SWL, indicating that the statewide models capture the nature of the controls on SWL.

\section{Local-Scale Factors}

Much of the analysis presented has focused on the relation of SWLs to statewide, generalized explanatory variables. It is likely, however, that finer scale variation in these factors (particularly local geology, local topography, local hydraulics, and density of wells in an area) may have an effect on SWLs in a particular area. The finer scale variables include more specific categories of bedrock type, landscape features, known groundwater-supply-problem areas, and areas where well replacement or deepening has occurred.

\section{Local-Scale Geology}

The models assessing SWLs described above were stratified by major bedrock geology groups (igneous and metamorphic) (table 9); however, it is possible that further refinement of the models to predict mean log SWL based on different geologic variables could be useful. A cursory analysis was done relating SWL data to the lithologic group in which each well is located. The lithologic group is a geologic variable representing differences in lithotectonic properties within the major geologic groups (Robinson and Kapo, 2003). The distributions of the data for mean quarterly SWL, total well depth, and length of casing in bedrock are shown by lithologic group and indicate that there may be significant differences between the mean log SWLs of some groups (fig. 11). For example, major differences can be seen among the lithologic groups that include granites; the alkali granites have lower SWLs than any other granite group. Wells in alkali granites, however, also have deeper overall well depths and longer casings in bedrock than wells in other rock types, indicating that the bedrock type itself may not be the only controlling factor. Differences between the mean log SWLs of metamorphic-rock groups, which include the calcpelite, pelitic rocks, and sulfidic schists, appear to be subtle. Thus, local-scale variation in SWLs can be expected in different bedrock formations. Future efforts to examine SWL variability by geology would likely be improved by a more rigorous examination of bedrock geologic data.

\section{Static Water Levels in Areas with Known Groundwater-Supply Concerns}

In some areas of the state and, specifically, in more densely developed towns, clusters of wells, commonly within the same geologic formation, have been reported to have deep SWLs and (or) limited yields (B. Kernen, New Hampshire Department of Environmental Services, written commun., 2010). In areas characterized by low-yield or deep-SWL wells, obtaining an adequate, reliable water supply can be problematic. Most of these areas are in the southern part of the state, where population pressures and demand for water are most intense. Towns in which water supply in specific areas has been reported to be limited include Derry, Plaistow, Pelham, Kingston, Bedford, and Windham. The limitations of the water supplies in these towns has 

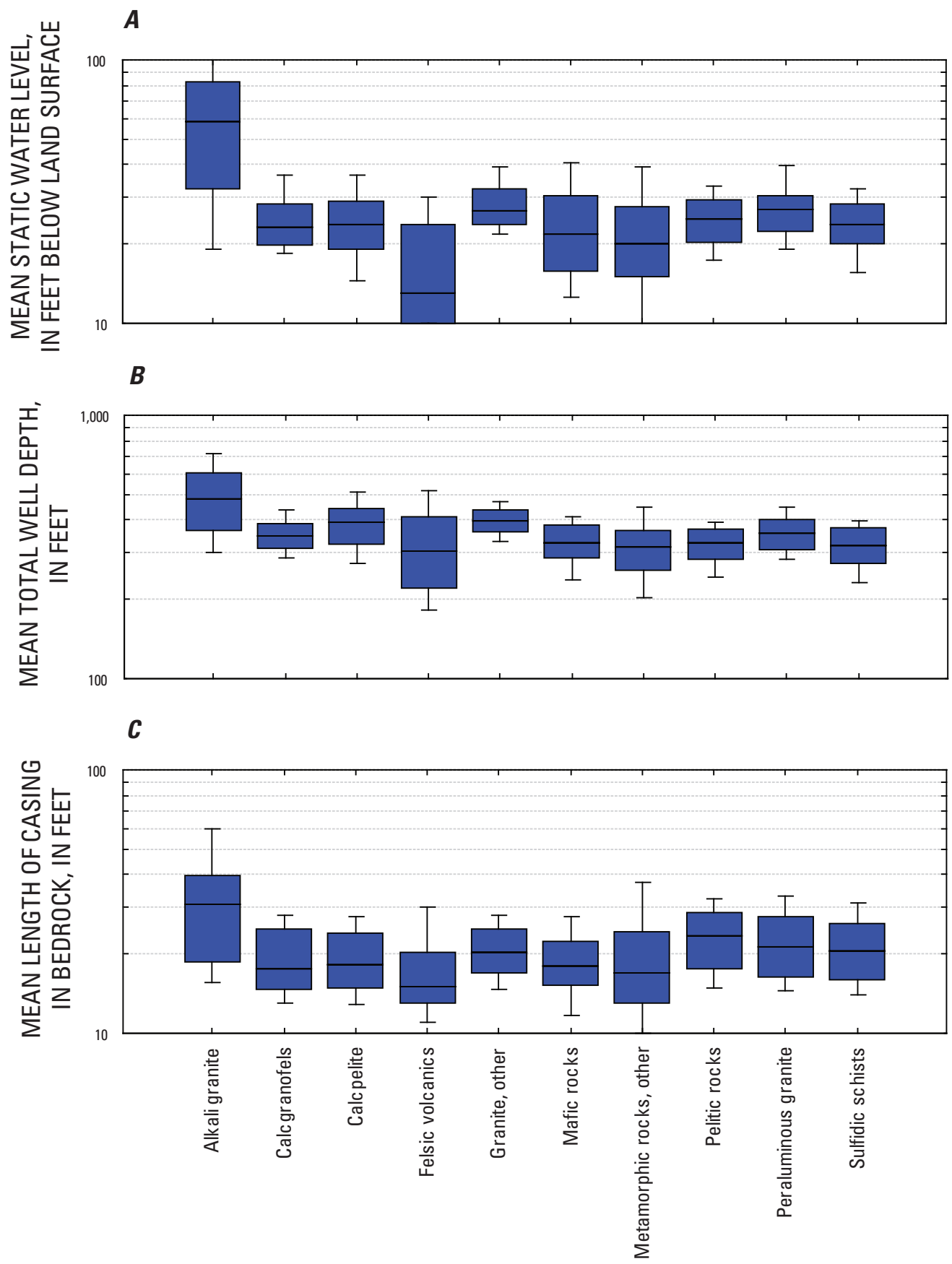

EXPLANATION

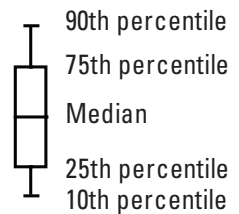

Figure 11. Boxplots summarizing A) mean quarterly static water level, B) mean total well depth, and C) mean length of casing in bedrock for major lithologic groups in New Hampshire (groups from Robinson and Kapo, 2003). 
prompted concern about the possibilities of local-to-regional water-level declines and pumping-well interference (converging contributing areas or capture zones). In some of these towns, rates of increase (deepening) of the mean SWL are more than twice that of the statewide rate of about $0.5 \mathrm{ft} / \mathrm{yr}(0.15 \mathrm{~m} / \mathrm{yr})$. Unaggregated water-level data from individual wells in these six towns were used to examine relations of the mean SWL to possible controlling factors.

As indicated by the statewide multiple regression models, mean SWL is deeper for wells higher on hillslopes relative to nearby low elevations (within 1,640 ft $(500 \mathrm{~m})$ ) than for wells at lower elevations relative to the surrounding area. For this local analysis, individual wells were grouped into categories of HAVB and aspect. HAVB categories were less than $100 \mathrm{ft}$ $(30 \mathrm{~m}) \mathrm{HAVB}$ and greater than or equal to $100 \mathrm{ft}(30 \mathrm{~m}) \mathrm{HAVB}$, which represents the 75 th percentile of the statewide values. Aspect indicates the azimuthal direction of the sloping face of the land surface, where north refers to greater than or equal to 300 degrees to less than or equal to 60 degrees. South refers to greater than 60 degrees to less than 300 degrees. In general, for wells that were categorized as less than $100 \mathrm{ft}(30 \mathrm{~m}) \mathrm{HAVB}$, there was no notable difference in the mean SWLs; however, SWLs in wells in the category of more than $100 \mathrm{ft}(30 \mathrm{~m})$ HAVB were deeper on dominantly south-facing hillslopes than on dominantly north-facing hillslopes (fig. 12). These relations were most pronounced for wells in Pelham, where the high-relief, south-facing wells had a mean SWL of $58.4 \mathrm{ft}(17.8 \mathrm{~m})$ compared to $40.5 \mathrm{ft}(12.3 \mathrm{~m})$ for the north-facing wells and less than $30 \mathrm{ft}(9.1 \mathrm{~m})$ for either aspect category of the low-relief wells (fig. 12A). The same was true in Windham, where the mean SWL in the high-relief south-facing wells was at least $10 \mathrm{ft}(3 \mathrm{~m})$ greater than in any other category (fig. 12B). SWLs in Bedford (fig. 12C) and Goffstown (fig. 12D) showed similar trends; however, there were too few wells for this analysis for Kingston (fig. 12E) and Plaistow (fig. 12F).

Slope in the southerly direction is commonly steeper than the slope in the northerly direction, possibly causing SWLs to be deeper. This is consistent with landforms associated with glaciation in the region, where slopes are more gradual in the direction from which the glaciers advanced (generally the northwest) and steeper in the down-ice direction (generally southeast) (Flanagan and others, 1999). Another hypothesis is that the southern slopes have higher evapotranspiration rates, reducing recharge and leading to deeper SWLs. Other factors, such as aspect, slope-dependent overburden thickness, differential flow in unconsolidated and bedrock aquifers, or combinations of factors may act in concert to affect SWLs.

\section{Static Water Levels in Deepened and Replacement Wells}

Wells throughout the state are occasionally replaced or deepened, commonly in response to a need for adequate or additional water supply. Characteristics of these wells may provide additional insight into how or why mean SWLs vary. The locations of the replacement and deepened wells from the WWI database are shown in fig. 13 and are a subset consisting of 3,519 wells that include 115 wells installed for additional supply or for increased well depth and 3,404 wells to replace a supply well (commonly a shallow dug well). Both replacement and deepened wells were installed across much of the state and commonly in the same areas (fig. 13).

The deepened and replacement wells were aggregated by year and quarter, yielding 96 mean values for new and replacement wells and 56 for deepened wells. The other wells (identified as new wells) in the WWI database $(17,174)$ are included on the graphs for comparison purposes. Mean depth to SWL in the deepened wells is greater than in the replacement and all new wells (fig. 14A). Also, the mean total depth of well is greater in the deepened wells (fig. 14B). This result is consistent with the result that well depth is a significant control on SWL. The reason for this is unclear, but may be related to lower heads and yields in deeper wells (in recharge zones). Additional information can be drawn from data on elevation and local relief (represented by HAVB). For example, there is no significant difference in the mean elevations of these wells among the three well categories (fig. 14C), indicating that this variable is not a potential factor in explaining SWL differences. The mean HAVB, however, is significantly larger for wells that were deepened or drilled for additional yield (fig. 14D). This further indicates that local relief, as described for other analyses in this report, may play an important role in controlling depth to SWL. 

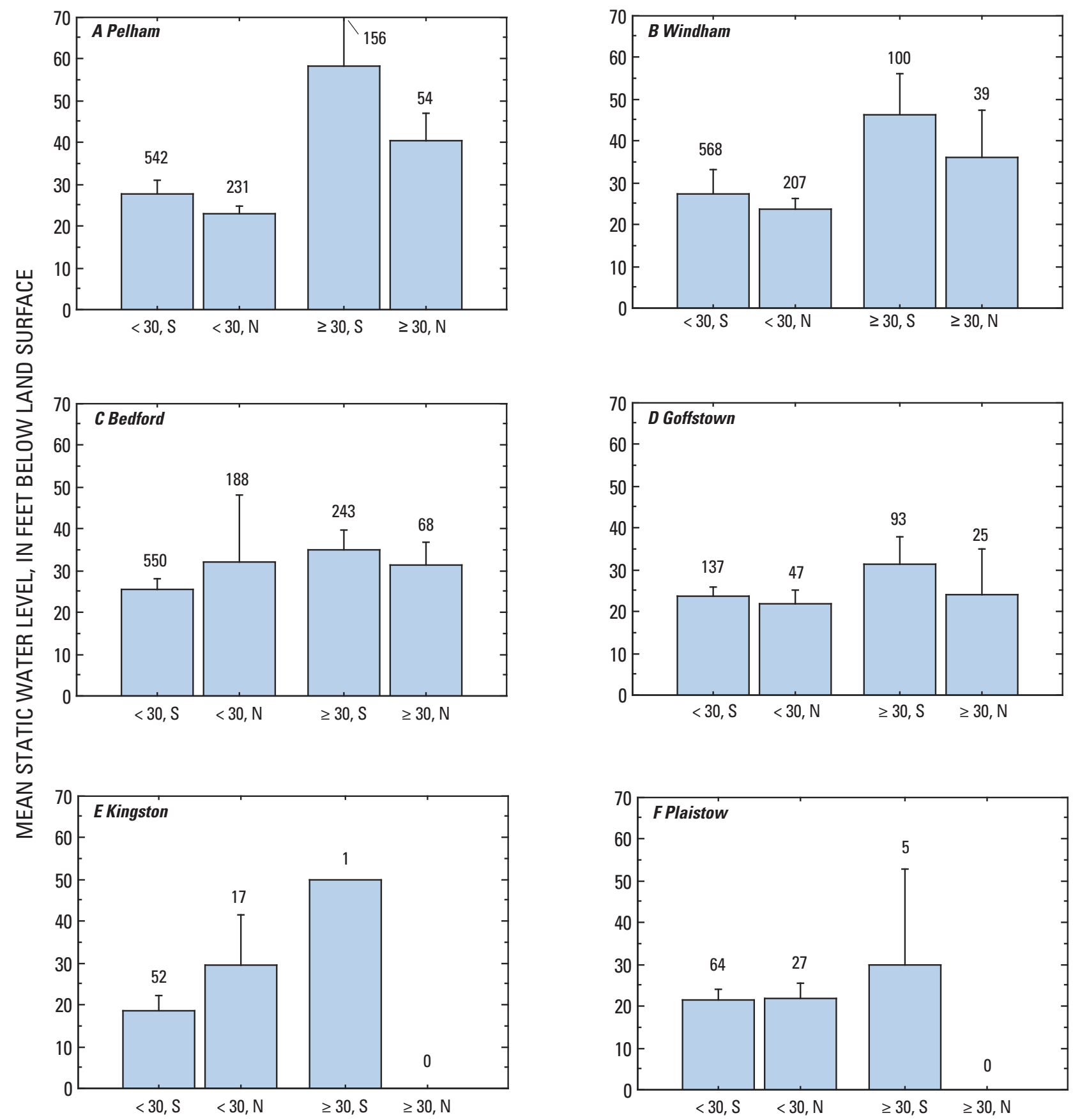

Figure 12. Bar graphs showing relation of mean static water level to binary categories of height of well above minimum elevation within a 1,640-foot (500-meter) radius of well ( $<100$ feet ( 30 meters) and $\geq 100$ feet ( 30 meters)) and aspect ( $N$ refers to $\geq 300$ degrees and $\leq 60$ degrees; $S$ refers to $>60$ degrees and $<300$ degrees), by town. Data from 1994-2008 [error bar represents 95 -percent confidence interval of the mean; number above bar represents the number of samples]. 


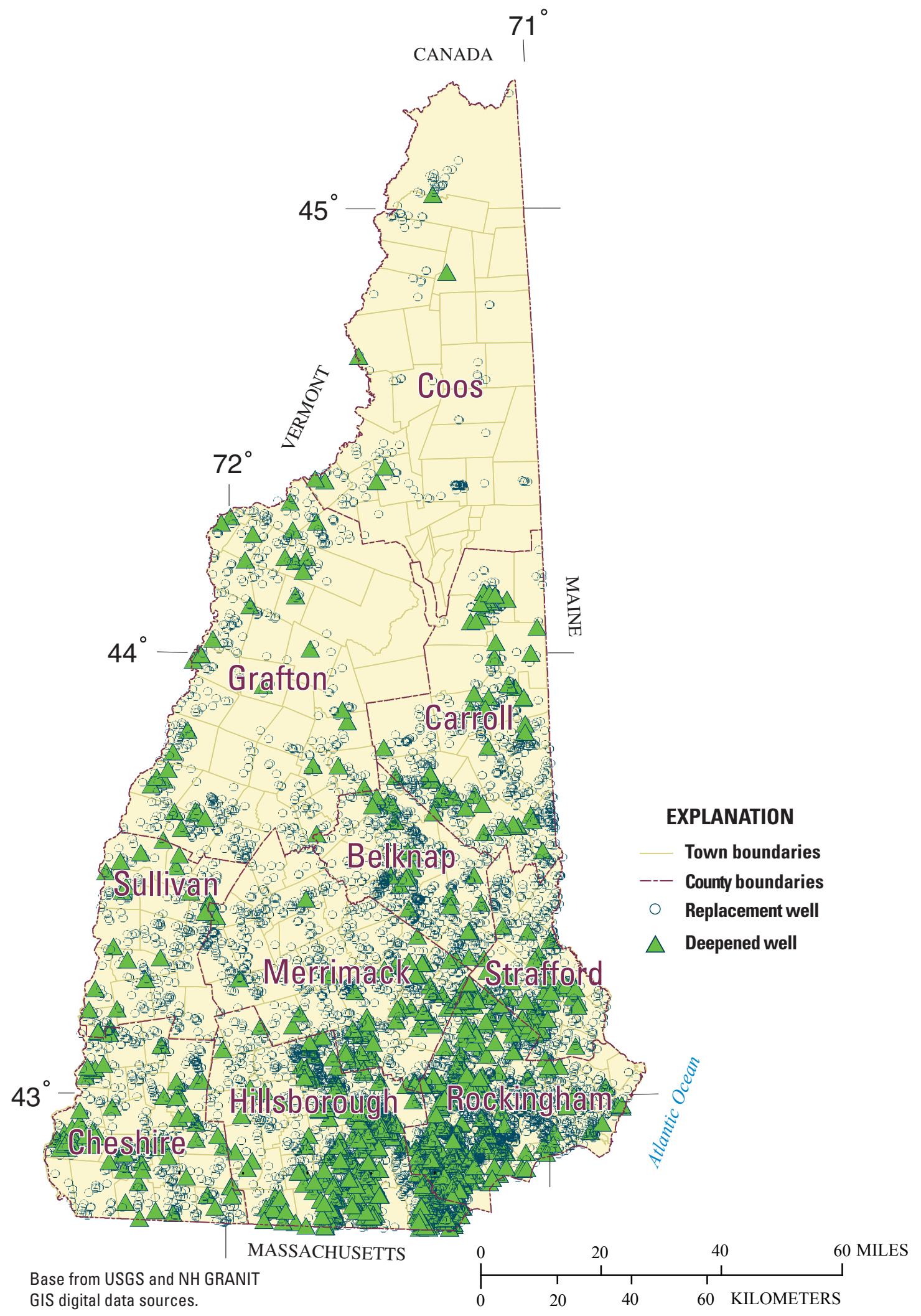

Figure 13. Map showing locations of wells reported as replacement wells (black circles) or deepened wells (green triangles) in New Hampshire, 1984-2007. 

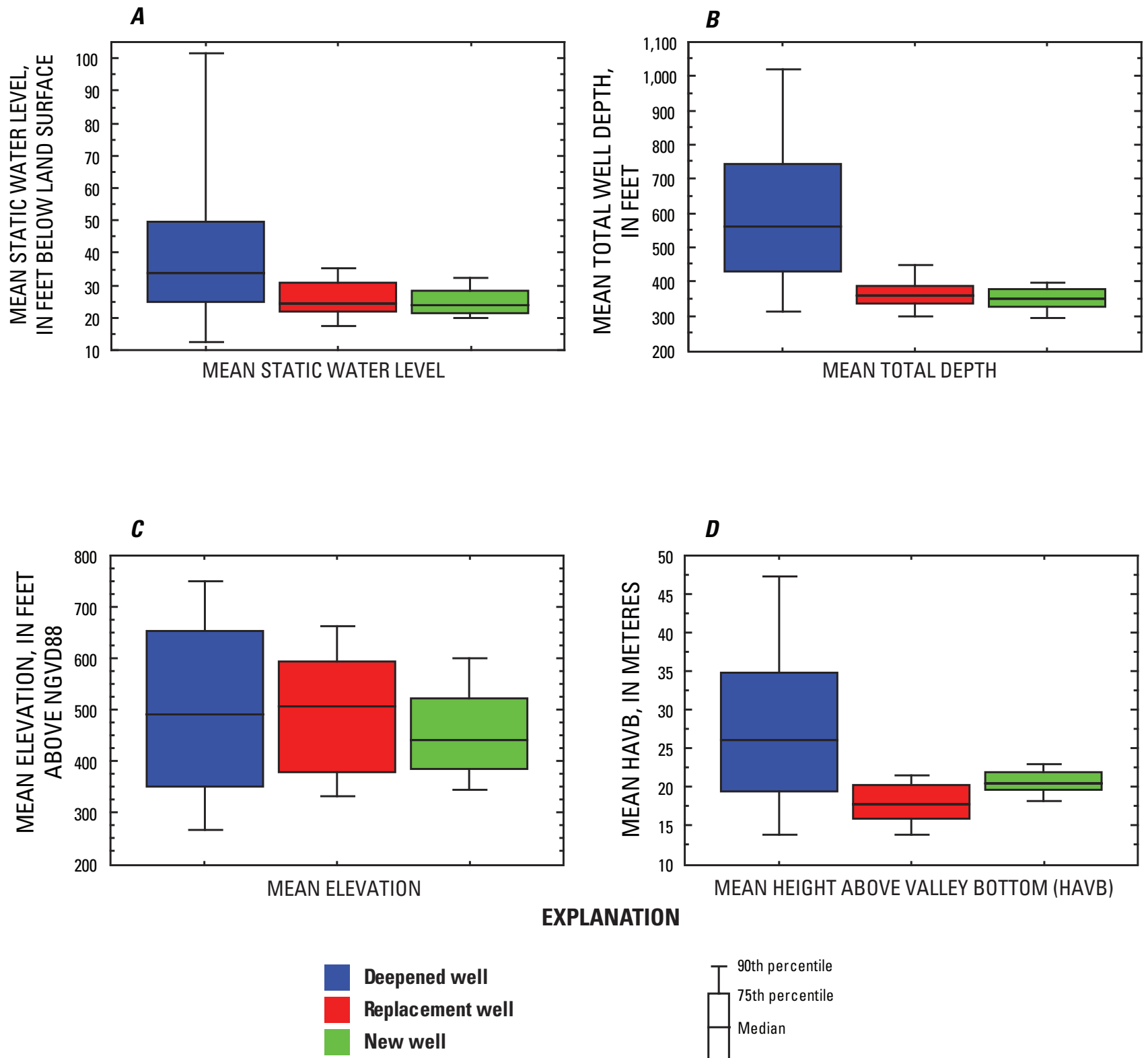

EXPLANATION

Figure 14. Graphs showing A) mean static water level, B) mean total well depth, C) mean elevation, and D) mean height above minimum elevation within a 1,640-foot (500-meter) radius of well (HAVB), by categories of reported reason for well installation, New Hampshire, 1984-2007. 


\section{Summary and Conclusions}

A cooperative investigation involving the New Hampshire Department of Environmental Services, the New Hampshire Geological Survey, and the U.S. Geological Survey was initiated in 2008 to explore potential trends in static water levels (SWLs) in wells and possible factors related to SWLs statewide, regionally, and locally. Analysis of nearly 60,000 reported values of SWL in new, deepened, and replacement bedrock wells in New Hampshire, aggregated on a yearly basis, showed an apparent deepening of SWL by about 13 feet over the period 1984-2007. These apparent declines are of concern because of the possible implications for water supply from the bedrock-aquifer system in New Hampshire. The same data also indicate that other well characteristics have also been changing over time, such as total well depth, casing length, the length of casing in bedrock, and to some extent, well yield. The average elevation of wells also has varied with time. In addition, SWLs were significantly lower in areas of high relief. Many of the well-construction variables are significantly correlated with SWLs. Because it is likely that several variables are needed to explain the variance in SWL over time, the main correlates (total depth, casing length, length of casing in bedrock, and well yield), as well as ancillary variables (season, hillslope position, elevation, recharge, precipitation, and geology), were considered in multiple regression analyses.

The most significant predictors of mean SWL (as indicated by multiple regression models) were total depth, the third quarter of the year (July-September), elevation, and height above minimum elevation within a 1,640-foot (500-meter) radius of the well (hillslope factor). Casing length was a significant covariate for depth to SWL of wells in igneous rock and curvature of the land surface for wells in metamorphic rock. Most of the covariates were significant also for county-scale models, indicating that the statewide model sufficiently accounts for coarse-scale features that affect SWLs in bedrock wells. Local variations in geologic formations as well as landscape features appear to provide further explanation of SWL variation. For example, SWLs in wells completed in specific granites appear to be deeper than in other granites; a similar relation was also observed for groups of metamorphic rocks.

A more detailed examination of data from six towns that report frequent complaints about lack of water from bedrockaquifer wells indicates that hillslope position may play a role in the availability of well water in these towns. SWLs were commonly deeper in wells with more than $100 \mathrm{ft}(30 \mathrm{~m})$ of relief between the well and the lowest land-surface elevation within a radius of 1,640 ft $(500 \mathrm{~m})$ of the well. Additionally, in these high-relief wells, the depth to SWL was commonly greater in wells on generally south-facing slopes than in wells on north-facing slopes. Although the reasons for this relation are not clear, it is possible that glacial morphology (steeper slopes facing south than north) and possibly evapotranspiration effects could play a role.

Concerns about wells with low water-producing capacity in localized areas within towns may be better understood by considering some of the relations identified in this study. For example, the data show that the hillslope position of a well affects the SWL depth in that well; however, the data also indicate that the average yield of the well is lower for hillslope wells. These relations indicate that as the hillslope factor increases (and SWLs get deeper), the amount of available water in the wells decreases. Knowledge of this relation may lead to the drilling of deeper wells in areas of high hillslope variability. In areas with less extreme relief, the overall depth of wells has increased substantially more than the decrease in SWLs. This indicates that the amount of water stored in wells (wellbore storage) has increased and, thus, more water is available for use in the average well. As a result, more water may be used because it is available, possibly adding to the problem of local well interferencewhere adjacent wells influence the availability of water to the well—or exacerbating drought-related well problems. This study did not, however, assess anthropogenic factors such as water-use patterns over time to explain apparent water-level observations; an accounting of these factors would be needed to more fully explain the water-capacity issues.

These data provide an opportunity to examine groundwater-level conditions across the state, but they cannot substitute for a carefully designed network of wells selected for the sole purpose of monitoring SWLs. The data do allow for analysis that may be considered in the design of a monitoring network, and continued collection of water-well data from the bedrock wells could be used to augment data from monitoring wells.

\section{References Cited}

Ayotte, J.D., Argue, D.M., McGarry, F.J., Degnan, J.R., Hayes, L., Flanagan, S.M., and Helsel, D.R., 2008, Methyl tert-butyl Ether (MTBE) in public and private wells in New Hampshire: occurrence, factors, and possible implications: Environ. Sci. Technol., v. 42, no. 3, p. 677-684.

Brutsaert, W., 2010, Annual drought flow and groundwater storage trends in the eastern half of the United States during the past two-third century: Theoretical and Applied Climatology, v. 100, no. 1, p. 93-103. 
Chormann, F.H., 1990, Bedrock water wells in New Hampshire: a statistical summary of the 1984-1990 inventory: New Hampshire Department of Environmental Services NHDES-WRD-90-3, 26 p.

Drew, L.J., Schuenenmeyer, J.H., Armstrong, T.R., and Sutphin, D.M., 2001, Initial yield to depth relation for water wells drilled into crystalline bedrock--Pinardville Quadrangle, New Hampshire: Ground Water, v. 39, no. 5, p. 676-684.

Flanagan, S.M., Nielsen, M.G., Robinson, K.W., and Coles, J.F., 1999, Water quality assessment of the New England Coastal Basins in Maine, Massachusetts, New Hampshire, and Rhode Island-environmental settings and implications for water quality and aquatic biota: U.S. Geological Survey Water-Resources Investigations Report 98-4249, 62 p.

Flynn, R.H., and Tasker, G.D., 2004, Generalized estimates from streamflow data of annual and seasonal ground-water recharge rates for drainage basins in New Hampshire: U.S. Geological Survey Scientific Investigations Report 2004-5019, 61 p.

Hayhoe, K., Wake, C., Huntington, T., Luo, L., Schwartz, M., Sheffield, J., Wood, E., Anderson, B., Bradbury, J., DeGaetano, A., Troy, T., and Wolfe, D., 2007, Past and future changes in climate and hydrological indicators in the US Northeast: Climate Dynamics, v. 28, no. 4, p. 381-407.

Helsel, D.R., 2005, Nondetects and data analysis (1st ed.): Hoboken, N.J., John Wiley and Sons, Inc., 250 p.

Helsel, D.R., and Hirsch, R.M., 1992, Statistical methods in water resources: New York, Elsevier Science Company, Inc., 522 p.

Helsel, D.R., Mueller, D.K., and Slack, J.R., 2006, Computer program for the Kendall family of trend tests: U.S. Geological Survey Scientific Investigations Report 2005-5275, 8 p.

Hirsch, R.M., and Slack, J.R., 1984, A nonparametric trend test for seasonal data with serial dependence: Water Resources Research, v. 20, no. 6, p. 727-732.

Hodgkins, G.A., and Dudley, R.W., 2006, Changes in the timing of winter-spring high streamflows in eastern North America 1912-2002: American Geophysical Union, Geophysical Research Letters, v. 33.

Hodgkins, G.A., Dudley, R.W., and Huntington, T.G., 2005, Summer low flows in New England during the 20th century: Journal of the American Water Resources Association, v. 41, no. 2, p. 403-412.

Horn, M.A., Moore, R.B., Hayes, L., and Flanagan, S.M., 2007, Methods and estimates of 2003 and projected water use in the Seacost region, southeastern New Hampshire: U.S. Geological Survey Scientific Investigations Report 2007-5157, 87 p.

Mack, T.J., 2009, Assessment of ground-water resources in the Seacoast region of New Hampshire: U.S. Geological Survey Scientific Investigations Report 2008-5222, 52 p.

Menard, S., 2002, Applied logistic regression analysis: Thousand Oaks, Calif., Sage Publications, Inc., 111 p.

Moore, R.B., Schwarz, G.E., Clark, S.F., Jr., Walsh, G.J., and Degnan, J.R., 2002, Factors related to well yield in the fracturedbedrock aquifer of New Hampshire: U.S. Geological Survey Professional Paper 1660, 51 p.

National Climatic Data Center, 2009, Monthly precipitation data for Concord, Durham, and Portsmouth, New Hampshire: National Oceanic and Atmopsheric Administration, accessed March 5, 2009, at http://www.ncdc.noaa.gov/oa/ncdc.html.

Nolan, B.T., and Hitt, K.J., 2006, Vulnerability of shallow groundwater and drinking-water wells to nitrate in the United States: Environmental Science and Technology, v. 40, no. 24, p. 7834-7840.

Robinson, G.R., Jr., and Kapo, K.E., 2003, Generalized lithology and lithogeochemical character of near-surface bedrock in the New England region: U.S. Geological Survey Open-File Report 03-225, 60 p.

Rutledge, A.T., 1993, Computer programs for describing the recession of ground-water discharge and for estimating mean ground-water recharge and discharge from streamflow record: U.S. Geological Survey Water-Resources Investigations Report 93-4121, 45 p.

Rutledge, A.T., 1998, Computer programs for describing the recession of ground-water discharge and for estimating mean ground-water recharge and discharge from streamflow records-update: U.S. Geological Survey Water-Resources Investigations Report 98-4148, 43 p.

SAS Institue, 1999, StatView: reference guide (5.0.1 ed.), SAS Institute. 
SAS Institute Inc., 2008, SAS OnlineDoc 9.1.3, SAS Institute, Inc., v. 2008.

Skinner, K.D., Bartolino, J.R., and Tranmer, A.W., 2007, Water-resource trends and comparisons between partial-development and October 2006 hydrologic conditions, Wood River Valley, South-Central Idaho: U.S. Geological Survey Scientific Investigations Report 2007-5258, 30 p.

U.S. Census Bureau, 2001, Census block demographics Summary File 1 (SF1) for New Hampshire, accessed September 17, 2003, at http://arcdata.esri.com/data/tiger2000/tiger_download.cfm.

U.S. Census Bureau, 2006, 2006 Second edition TIGER/Line files, accessed December 15, 2006, at http://www.census.gov/geo/ www/tiger/tiger2006se/tgr2006se.html.

U.S. Census Bureau, 2009, State \& county quick facts: U.S. Census Bureau, accessed Aug. 26, 2009, at http://quickfacts.census. gov/qfd/states/33000.html.

U.S. Geological Survey, 1993, 1:250,000 Digital Elevation Model: U.S. Geological Survey, accessed April 11,, 2003, at http://edc.usgs.gov/geodata/.

U.S. Geological Survey, 2004, 1:24,000 Digital Elevation Model, National Elevation Dataset: U.S. Geological Survey, accessed June 8, 2004, at http://edc.usgs.gov/geodata/.

U.S. Geological Survey, 2008, National Water Information System: U.S. Geological Survey, accessed September 12, 2008, at http://waterdata.usgs.gov/nwis.

Wunsch, D.R., and Bennett, D.S., 2004, Water well data has multiple uses: Water Well Journal, v. 58, no. 3, p. 24-26. 
Prepared by the Pembroke Publishing Service Center.

For more information concerning this report, contact:

Director

U.S. Geological Survey

New Hampshire-Vermont Water Science Center

331 Commerce Way, Suite 2

Pembroke, NH 03275

dc_nh@usgs.gov

or visit our Web site at:

http://nh.water.usgs.gov 

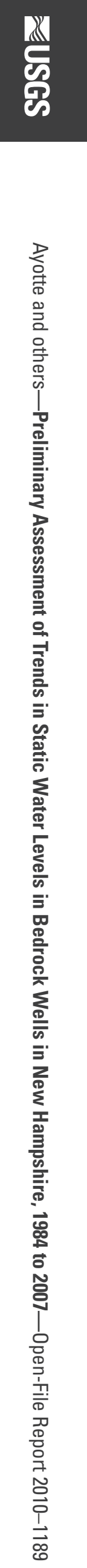